\title{
Intracerebral Adrenal Medulla Grafts: A Review
}

\author{
William J. Freed, Maciej Poltorak, and Jill B. Becker* \\ Preclinical Neurosciences Section, Neuropsychiatry Branch, NIMH Neuroscience Center at St. Elizabeths, Washington, D.C. 20032; and \\ ${ }^{*}$ Department of Psychology and Neuroscience Program, University of Michigan, Ann Arbor, Michigan 48104
}

This review summarizes basic and clinical research on intracerebral adrenal medulla grafts, emphasizing potential applications to Parkinson's disease. Properties of intraventricular and intraparenchymal grafts are described, and cell survival and functional effects are compared. It is clear that adrenal medulla allografts survive poorly in the parenchyma of the corpus striatum and better in the lateral ventricle. Nerve growth factor (NGF) may improve the survival of adrenal medulla grafts. In the absence of added NGF even adrenal medulla grafts in the ventricle survive irregularly, and the factors required for graft survival in the ventricle are not well understood. In the 6-hydroxydopamine-lesioned rat model most evidence suggests, not surprisingly, that adrenal medulla grafts produce functional effects only when they survive. These effects may be related to production of catecholamines by the transplanted cells. In addition, adrenal medulla grafts may produce trophic effects on host brain. These effects are most evident in animals with MPTP-induced damage to dopaminergic systems and may be nonspecific, possibly related in part to the brain injury that is induced by graft implantation. Trophic effects may contribute to the functional effects of adrenal medulla grafts: For intraparenchymal grafts, trophic effects that do not require cell survival may contribute small functional changes, while additional behavioral effects may require substantial chromaffin cell survival. The evidence for direct dopamine-mediated effects as compared to trophic mechanisms of action for these grafts in animal models for Parkinson's disease is presented. Clinical studies of adrenal medulla grafts in human patients are examined and compared in detail. When inspected closely, the various clinical studies are in general agreement on most points, although there are differences in the degree of improvement found, both across different studies and individual patients. It is concluded that some beneficial clinical effects occur, with small to modest changes in most patients and substantial improvement in a minority of patients. There also seem to be larger or more consistent changes in durations of "on" and "off" times in L-dihydroxyphenylalanine-treated patients. There are substantial side effects, and it is not clear that the clinical changes are sufficient to justify performing adrenal medulla trans- plantation in human patients as a routine procedure. The findings of clinical studies are generally consistent with the predictions that would have been made from animal studies; however, it is not clear whether some of the clinical effects could be nonspecific consequences of lesioning or surgery. Additional basic research would be required to develop a consistently effective clinical procedure. Remaining unanswered questions include the relative contributions of dopamine production and trophic changes to the functional effects of adrenal medulla grafts, the factors required for adrenal medulla graft survival, and the factors responsible for the substantial improvement that has been seen in some patients. The review concludes with a series of recommendations for future basic and clinical research on adrenal medulla transplantation. $\odot 1000$ Academic Press, Inc.

\section{INTRODUCTION}

The concept that functional deficits consequent to substantia nigra (SN) ${ }^{1}$ lesions can be alleviated by tissue transplantation has attracted considerable attention, in part because of the potential application to Parkinson's disease, but also because it has served as a model for the general approach of altering impaired brain function through tissue transplantation. Two different kinds of tissue have primarily been employed for this purpose. The first, embryonic $\mathrm{SN}$, is a logical choice and there is a general consensus that the functional effects of SN grafts are due to reinnervation of host brain by neurites derived from the graft $(17,32,33,48,50,52$, $53,93,111)$. The ultimate limitations of embryonic SN for transplantation involve ethical and practical problems related to donor tissue source and immunological barriers. The other frequently used donor tissue type, adrenal medulla from relatively mature animals, is also

\footnotetext{
${ }^{1}$ Abbreviations used: 6OHDA, 6-hydroxydopamine; bFGF, basic fibroblast growth factor; CSF, cerebrospinal fluid; $D B H$, dopamine $\beta$ hydroxylase; DOPAC, dihydroxyphenylacetic acid; L-DOPA, L-dihydroxyphenylalanine; MPTP, 1-methyl-4-phenyl-1,2,3,6-tetrahydropyridine; NGF, nerve growth factor; PNMT, phenylethanolamine $N$-methyltransferase; SN, substantia nigra; TFS, total function score; $\mathrm{TH}$, tyrosine hydroxylase.
} 
functionally effective (49). While the functional effects of adrenal medulla grafts may be less than those of SN grafts, tissue donor and rejection problems are avoided. The reasons for the functional effects of adrenal medulla grafts are somewhat uncertain. Despite this uncertainty, adrenal medulla autografts have been applied to hundreds of human patients, and even to some diseases other than Parkinson's disease including progressive supranuclear palsy and intractable pain (e.g., (82, $160,161)$ ). The purpose of the present paper is to review the basic and clinical data on the properties of adrenal medulla grafts, present the various hypotheses for the mechanisms of action of adrenal medulla grafts, and discuss the clinical data in light of these various hypotheses.

\section{SOME PROPERTIES OF ADRENAL CHROMAFFIN CELLS}

Adrenal chromaffin cells produce and secrete catecholamines (80). Catecholamine biosynthesis is regulated by a combination of neuronal and endocrine signals (149). In particular, the activity of phenylethanolamine $N$-methyltransferase (PNMT), which catalyses the synthesis of epinephrine from norepinephrine, is maintained by glucocorticoids from the adrenal cortex (165).

Adrenal chromaffin cells, even when taken from mature animals, can undergo a partial morphological transformation, including development of processes, when removed from the adrenal gland and either grown in tissue culture (154-159) or transplanted to the anterior eye chamber $(103,104,143,144)$. Adrenal chromaffin cells are capable not only of developing processes, but also may innervate brain tissue cotransplanted to the anterior eye chamber (104). The degree of morphological transformation exhibited by the normally round adrenal chromaffin cell can range from the development of an elongated shape to short coarse cytoplasmic extensions and even to the development of long ramified processes $(29,61,143,151,154-158)$. This transformation is normally inhibited by the high concentrations of corticosteroids from adrenal cortex present in the adrenal medulla (154), so that some degree of transformation occurs when the cells are simply grown in isolation. Much more extensive process formation is, however, promoted by addition of nerve growth factor (NGF) to the medium $(144,150,154-156)$. Other substances, including ciliary neuronotrophic factor and C6-glioma conditioned medium also promote neurite outgrowth from adrenal chromaffin cells $(136,157-159)$.

\section{PROPERTIES OF ADRENAL MEDULLA GRAFTS IN ANIMALS}

\section{A. Intraventricular Adrenal Medulla Grafts}

There have been surprisingly few studies of the effects of intraventricular adrenal medulla grafts in ani-

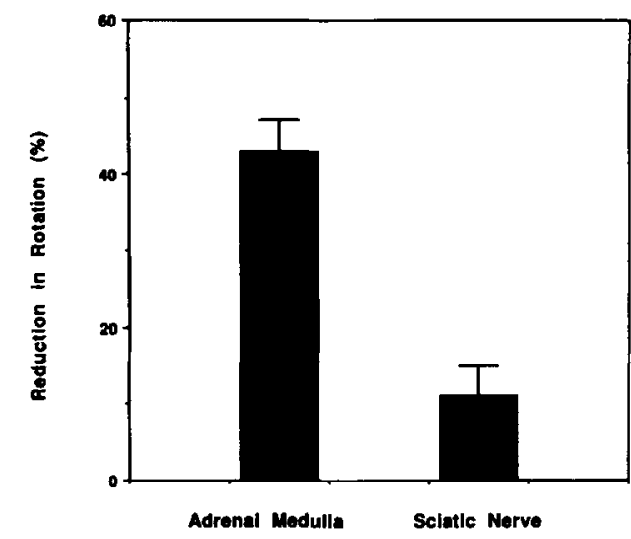

FIG. 1. Effects of intraventricular adrenal medulla grafts compared to those of sciatic nerve grafts on apomorphine-induced rotational behavior in rats (data from Ref. (49)). Donors were young adult rats, between 5 and 7 weeks of age. Each host received grafts from adrenal medulla or a similar amount of sciatic nerve in the lateral ventricle.

mal models of Parkinson's disease. In the first study of adrenal medulla grafts by our group (49), we found that grafts of adrenal medulla taken from young adult donors decreased apomorphine-induced rotational behavior (Fig. 1). This behavioral measure is used in animals to indicate the severity of unilateral SN lesions. The ability of adrenal medulla grafts to decrease rotational behavior has been replicated by several groups $(12,15$, $34,37,114,146)$, while one recent study by Brown and Dunnett in which the grafts did not survive found no effect (20). Our initial study of intraventricular adrenal medulla grafts found consistently substantial numbers of surviving catecholamine-containing cells, from 66 to $4080($ mean $=1535)$ per host animal $(49)$. This nevertheless represents a minority of the cells that were implanted.

Intraventricularly transplanted chromaffin cells show a range of morphologies. In some grafts, either where small amounts of adrenal cortex is included, or even without inclusion of adrenal cortex where the medulla remains relatively intact, the cells exhibit a rounded shape (Fig. 2).Chromaffin cells in adrenal medulla grafts can be identified by immunoreactivity for chromogranin A, tyrosine hydroxylase (TH), and dopamine $\beta$-hydroxylase (DBH). There is a decrease in the expression of PNMT immunoreactivity (Fig. 3). Where isolated small groups of cells are seen, the cells may develop short processes or coarse cytoplasmic extensions. Of 758 chromaffin cells examined in intraventricular grafts, only $11 \%$ were classified as having processes and $17 \%$ were described as having coarse cytoplasmic extensions, with the remaining $72 \%$ exhibiting round or elongated shapes $(42,50)$. None of these processes entered into the host brain, and all remained within the graft itself. Electron microscopic studies of transplanted adrenal chromaffin cells by Jousselin-Hosaja 

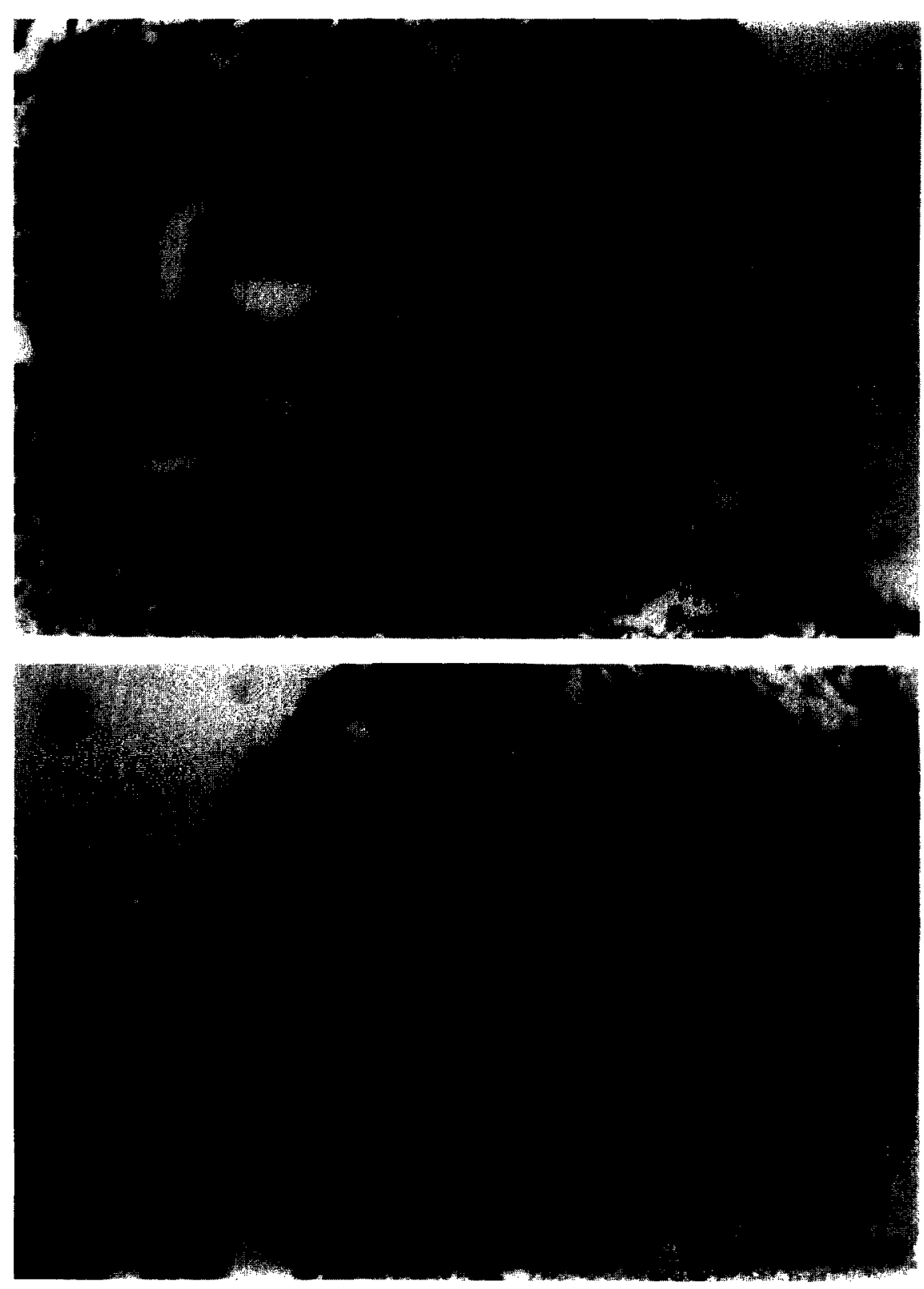

FIG. 2. An adrenal medulla allograft in the lateral ventricle of a rat brain with a large number of surviving chromaffin cells. The donor was a young adult animal weighing between 200 and $250 \mathrm{~g}$. (A) Hematoxylin- and eosin-stained paraffin section, showing numerous surviving chromaffin cells (bent arrow) and numerous blood vessels. (B) Numerous TH-immunoreactive chromaffin cells can be seen around blood vessels (peroxidase-antiperoxidase technique; $\mathrm{TH}$ antibody provided by William Tank, University of Rochester). The ventricle can be seen at the left of both figures. Calibration bar $=100 \mu \mathrm{m}$. Note the rounded, endocrine shape of the cells.

(76) showed that transplanted cells in the subarachnoid space tended to remain round or cuboidal with a few short processes, while cells in grafts in the hippocampal parenchyma showed more extensive process formation (76).

In a subsequent biochemical study (47), we confirmed that these grafts consistently contain substantial amounts of dopamine, norepinephrine, and epinephrine. Dopamine concentrations in the striatum adjacent to adrenal medulla grafts are also increased $(12,26)$. It is striking that the concentrations of dopamine in adrenal medulla grafts were extremely variable, ranging over four orders of magnitude $(42,47)$. This is consistent with other studies showing that concentrations of dopamine in the adrenal medulla in vivo tend to be very variable, changing markedly in response to manipulations such as the administration of various drugs (139). In another more recent study, however, we found much less variability in adrenal medulla graft dopamine concentrations (12). It is possible, therefore, that the 

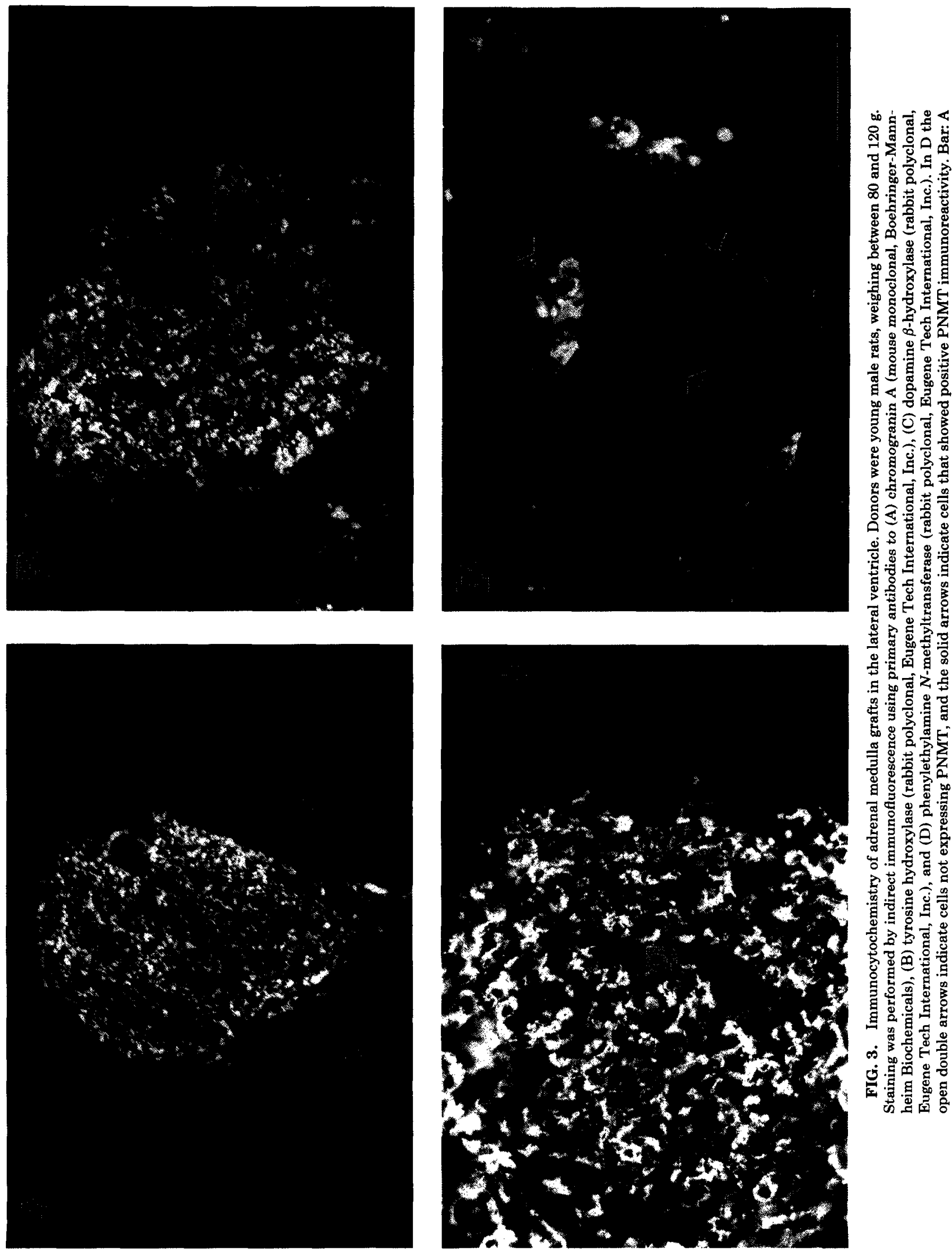

b 업

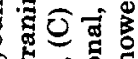
है 要

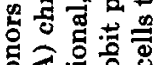
ㄴํㅇ용 $\div 8$. 号要思要 웡 ॠ

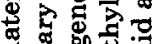
옹영

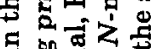
.

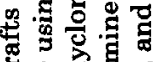
형영

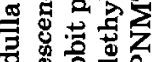
要跑要 要突总合密

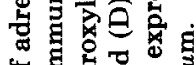

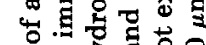

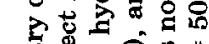
兽焉焉离

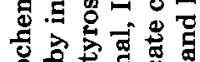

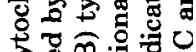
过氜

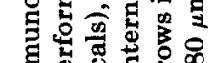

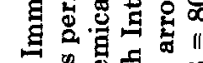

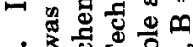
ஸ

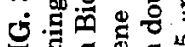

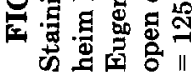


greater variability in dopamine concentrations in the grafts from the earlier study was due to greater inconsistency in dissection and transplantation techniques. In many cases, dopamine concentrations in adrenal medulla grafts greatly exceeded the concentrations of dopamine found in the intact striatum (46), strongly suggesting that at least some of the dopamine found in the graft samples was produced within the grafts, not by the host brain. In host animals with SN lesions, epinephrine concentrations in adrenal medulla grafts were increased and dopamine concentrations were decreased (47), suggesting the possibility that the host brain exerts an influence on intraventricular adrenal medulla grafts.

We have recently found that, when bilaterally transplanted into the lateral ventricles of neonatal rats, adrenal medulla grafts consistently survived and contained numerous catecholamine-containing or $\mathrm{TH}$-immunoreactive cells when the hosts reached adulthood (137). When the animals bearing adrenal medulla grafts received bilateral SN lesions, they showed increased eating and drinking behavior, while controls that had received sciatic nerve grafts were aphagic and adipsic (137). Adrenal medulla grafts in this model were, however, less effective than embryonic SN grafts (135): Adrenal medulla grafts did not increase activity and the increased eating and drinking were not sufficient to sustain their body weights. Although the grafts survived consistently, there was no apparent relationship between the degree of behavioral effect in individual animals and the number of surviving cells, position of the grafts, or any other obvious histological parameter. Nevertheless, this study shows that adrenal medulla grafts can produce at least some functional effects other than reductions in rotational behavior.

We have also found that adrenal medulla is ineffective, according to behavioral measures, when taken from aging donors and transplanted either to the lateral ventricle (42) or directly into the striatum (45). Bovine adrenal chromaffin cell grafts from immature donors also appear to produce greater amounts of catecholamines than grafts from mature donors, when transplanted into the rat striatum (37). Tischler and coworkers (151) reported that most of the chromaffin cells from adult rat adrenal medulla lose the ability to respond to NGF in vitro. On the other hand, Hansen and co-workers (66) found that adrenal chromaffin cells from human donors aged $3-51$ years showed process formation in the presence of NGF. Also, grafts from aging donors survive well in the lateral ventricle (42). Recently, another study by Stromberg and co-workers reported that adrenal chromaffin cells from aging donors survive transplantation to the anterior eye chamber and form processes in response to NGF (142). The reasons that aging adrenal medulla is behaviorally ineffective are therefore unclear; however, these studies underscore the importance of behavioral or functional studies in evaluating the efficacy of intracerebral transplantation procedures.

\section{B. Intrastriatal Adrenal Medulla Grafts}

Because of the initial supposition that the functional effects of adrenal medulla grafts were due to nonspecific release of catecholamines into the extracellular compartment, the lateral ventricle was not thought to be an ideal graft location. The prevailing assumption was that much of the catecholamines secreted by grafts in the lateral ventricle would be lost into the cerebrospinal fluid. For that reason, several studies were performed to determine whether adrenal medulla could successfully be transplanted into the striatal parenchyma, rather than into the ventricle.

Most of these studies have yielded negative or relatively discouraging results. Herrera-Marschitz and coworkers (70) and Stromberg and co-workers (145) found that the vast majority of the transplanted chromaffin cells died within a few hours after transplantation into the head of the caudate-putamen. These grafts produced substantial short-term behavioral effects during the first few hours after implantation that were attributed to release of catecholamines from degenerating cells. Subsequent studies of long-term effects of these grafts by Bing and co-workers (15), by our group (45), and by Stromberg and co-workers $(105,146)$, confirmed that relatively few transplanted cells in intrastriatal grafts (in contrast to intraventricular grafts) survived on a long-term basis $(45,105,146)$. $\Lambda \mathrm{n}$ avcrage of less than 100 cells per target transplantation site survive $(15,45)$ and the behavioral effects produced by these grafts are usually small. Dissociated chromaffin cell grafts in the striatal parenchyma also survive poorly $(15,20,109)$. In one of these studies (15) substantial decreases in rotational behavior over 4 weeks were observed, notwithstanding the fact that no more than 100 surviving cells were found in any of the animals.

One study of intrastriatal adrenal medulla grafts by Stromberg and co-workers (146) reported that chronic administration of NGF increases both the functional effects and the survival of chromaffin cells. It may be that the limited survival of adrenal medulla grafts in the striatal parenchyma is due to the low concentrations of NGF in this nucleus (83). Several additional factors could contribute to the poor survival of intraparenchymal adrenal medulla grafts, including relatively poor nutritional conditions in the parenchyma compared to those in the ventricle, the inevitable accumulation of blood in intraparenchymal implantation sites, and compression of the cells. Mature cells may not be able to withstand these conditions, in contrast to embryonic neurons. 
Another recent study by Brown and Dunnett (20) obtained poor survival of adrenal medulla grafts in the ventricle as well as in the brain parenchyma. Dissociated cell grafts in the brain parenchyma produced slight decreases in apomorphine-induced rotation, but intraventricular grafts produced no change. In light of earlier studies (15), this study tends to suggest that intraparenchymal adrenal medulla grafts may produce slight behavioral effects irrespective of whether the grafts survive, but that positive effects of intraventricular grafts require substantial chromaffin cell survival. Even in the ventricle, however, survival of adrenal medulla grafts is generally less consistent than survival of embryonic brain tissue grafts $(20,43,46)$.

In immunosuppressed rat hosts, Decombe and coworkers (27) obtained survival of large numbers of bovine chromaffin cells after transplantation into the' striatum in about half of the animals examined. These grafts did not decrease either amphetamine- or apomorphine-induced rotational behavior. Nicotine, which stimulates catecholamine release from the adrenal gland, induced contralateral rotation in all animals with surviving chromaffin cell grafts, but produced no effect in the animals that lacked surviving grafts. This effect of nicotine was not blocked either by pimozide or naloxone. Thus the reasons for this effect of adrenal medulla grafts are still open to question.

It should also be mentioned that adrenal medulla from newborn rat donors has been reported to undergo a greater morphological transformation than adult adrenal medulla, with substantial process formation, when transplanted into the rat brain (100). A decrease in amphetamine-induced rotational behavior was found; however, this decrease involved only a comparison with other transplanted rats from the same group that did not show decreases, and there was no comparison with a control group (100). Fetal adrenal medulla has also been transplanted into a single human patient (92).

\section{Xenografts}

Cultured human adrenal chromaffin cells have also been transplanted into prepared cavities in the cortex and striatum of rats (77). Surprisingly, these grafts were reported to survive for 4.5-6 months, with no evidence of rejection. Four of the eight animals with chromaffin cell grafts showed sustained reductions in amphetamine-induced rotation, while none of the six animals with control sciatic nerve implants showed decreases in rotational behavior. Several studies have, in fact, reported relatively long-term survival of chromaffin cell xenografts in nonimmunocompromised hosts $(37,77$, 112). In most of these experiments there is some uncertainty regarding histological identification of the chromaffin cells after transplantation. Possible misidentifi- cation of macrophages or other cells as chromaffin cells may have occurred. In none of the above studies of chromaffin cell xenografts in nonimmunosuppressed animals $(37,77,112)$ were surviving chromaffin cells clearly identified by immunocytochemical or morphological criteria.

In contrast, recent experiments which employed host animals immunosuppressed with cyclosporin $(27,126)$ clearly demonstrated numerous surviving bovine chromaffin cells after transplantation. In earlier studies of isolated bovine chromaffin cell xenografts into the periaqueductal gray matter or spinal cord of nonimmunosupressed hosts $(128,129,130)$, the grafts were found to survive even without immunosuppression and produced functional effects similar to those of allografts $((128,130)$, see below). Thus some survival of chromaffin cell xenografts may occur, even without immunosuppression. It was suggested that the absence of fenestrated peripheral-type capillaries in these xenografts may have contributed to their survival (126).

\section{Analgesic Effects and Opiates}

Adrenal chromaffin cell grafts produce an analgesic effect when transplanted into the rat spinal cord or periaqueductal grey $(125,127-130)$. Analgesia was induced by injection of nicotine, which stimulates release of catecholamines and opioid peptides from chromaffin cells. This effect was blocked by the opiate antagonist naloxone, strongly suggesting that these grafts function by releasing opioid peptides into surrounding host tissue. This hypothesis was further supported by subsequent studies that showed increased metenkephalinlike immunoreactivity in spinal cord CSF of animals with adrenal medulla grafts (124) and by studies showing that the duration of analgesia induced by nicotine in animals with adrenal medulla grafts could be prolonged by administration of the enkephalinase inhibitor kelatorphan (131). Secretion of catecholamines may also have contributed to the analgesic effect, as the analgesia was attenuated by the adrenergic antagonist phentolamine $(130,132)$, and increased catecholamines were found in spinal cord superfusates of animals with adrenal medulla grafts (79). Adrenal medulla grafts were also effective in a chronic pain model, using adjuvantinduced arthritis (132).

In this model of intracerebral chromaffin cell transplantation, therefore, it is probable that secretion of opioid peptides, and possibly catecholamines as well, is important for the achievement of functional effects. It is also possible that secretion of opioid peptides plays a role in the functional effects of adrenal chromaffin cell grafts in other model systems. There is a modest (about $50 \%$ ) decrease in $\beta$-endorphin in the CSF of patients with Parkinson's disease (97). Increased concentrations 
of metenkephalin in the CSF of human patients has been reported after intraventricular adrenal medulla transplantation (30), although this change has not been replicated. Adrenal grafts have been tried for therapy of intractable pain in human patients, but have produced little or no effect $(160,161)$.

E. Comments and Comparison of Grafts in the Ventricle and the Striatum

In summary, it appears that all factors which influence adrenal medulla graft survival are not known, as several studies have reported poor cell survival $(8,15$, $19,20,36,45,65,70,96,109)$ and others $(13,27,31,42$, $43,47,49,64,76,108,116,126-132,137,146)$ have found good survival of adrenal chromaffin cell grafts under various circumstances. Most data, however, suggest that functional effects of intraventricular adrenal medulla grafts in rats with 6OHDA-induced lesions of the $\mathrm{SN}$ are seen only when substantial numbers of transplanted chromaffin cells survive. Recent data by Decombe and co-workers (27) suggest that intraparenchymal adrenal medulla grafts, which do not otherwise alter the behavior of host animals, may produce rotational behavior when stimulated with nicotine, but only if the grafts survive.

In some experiments that have obtained behavioral effects in spite of poor cell survival $(15,20)$, it has been concluded that the grafts must operate by some other mechanism, not related to catecholamine secretion by the grafts. All of these experiments have involved grafts into the brain parenchyma rather than into the ventricle. This suggests that injury to brain tissue produced by these grafts is an important factor, although there is also the possibility that the intimate contact between the graft and host brain allows for some trophic interaction. In the following section (IV B), a second anatomical effect of adrenal medulla grafts $(8,15,36,54)$ is reviewed. This effect is primarily seen in animals with nigrostriatal damage induced by MPTP and could contribute to the behavioral effects of adrenal medulla grafts under some circumstances.

Thus at least in some experiments, adrenal medulla grafts can survive well when transplanted into the lateral ventricle, but not when transplanted into the parenchyma of the corpus striatum $(15,45,49)$. This is consistent with the better survival and larger size of solid embryonic brain tissue grafts in the lateral ventricle compared to the brain parenchyma $(101,115)$. Correspondingly, the long-term behavioral effects of adrenal medulla grafts are greater when the grafts are placed into the ventricle, compared to when they are placed into the striatum of the rat $(15,27,45,49,70,146)$. NGF appears to increase the survival of intraparenchymal adrenal medulla grafts in addition to increasing their behavioral effects $(114,146)$.

\section{MECHANISMS OF ACTION}

\section{A. Nonsynapric Catecholamine Release}

\section{Is It Conceivable That Nonsynaptic Dopamine Release Could Mediate Effects of Adrenal Medulla Grafts?}

There are several reasons to believe that diffuse release of dopamine into the striatum is at least potentially capable of alleviating some of the effects of SN lesions. Systemic administration of L-DOPA and direct dopamine agonists are therapeutically beneficial in the treatment of Parkinson's disease $(24,68,102)$ and can also be used to decrease behavioral deficits in animals after SN lesions $(89,94)$. Recent studies have shown that chronic local administration of dopamine into the striatum, either via osmotic pumps (67) or dopaminereleasing polymers $(14,164)$ decrease apomorphine-induced rotation in animals with SN lesions.

There is also evidence that neural grafts are capable of influencing surrounding host tissue through the diffuse release of chemical substances (16). Earlier studies showing that adrenal medulla grafts influence pain perception (125-132), probably through release of endorphins $(124,131)$, also support this possibility. Consequently, it seems conceivable that adrenal medulla grafts could act as paracrine tissues and influence the surrounding brain by releasing chemical substances into the interstitial space followed by diffusion.

\section{Release of Catecholamines into the Extracellular Space}

The mechanism of action of adrenal medulla grafts that was initially proposed was secretion of catecholamines followed by diffusion, i.e., a paracrine mode of action. This was suggested because these grafts did not reinnervate the host brain (Fig. 4), but in fact was not supported by any direct evidence. It was subsequently reasoned that, if the grafts operated by secreting catecholamines nonspecifically into the extracellular space, appreciable amounts of catecholamines should also be found in the ventricular cerebrospinal fluid (CSF) of these animals $(12,13)$. In animals with adrenal medulla grafts, however, no dopamine was found in the CSF even though dopamine metabolites in the CSF were increased (12) (Fig. 5). Clinical studies of adrenal medulla grafts in patients with Parkinson's disease have also found no increase in free dopamine in CSF, although dopamine sulfate was increased (153). In two abstracts it was also stated that dopamine was not increased in human patients that had received adrenal medulla grafts $(21,22)$. Thus it is improbable that the functional effects of adrenal medulla grafts are due to diffusion of dopamine from the grafts into surrounding tissues; if 


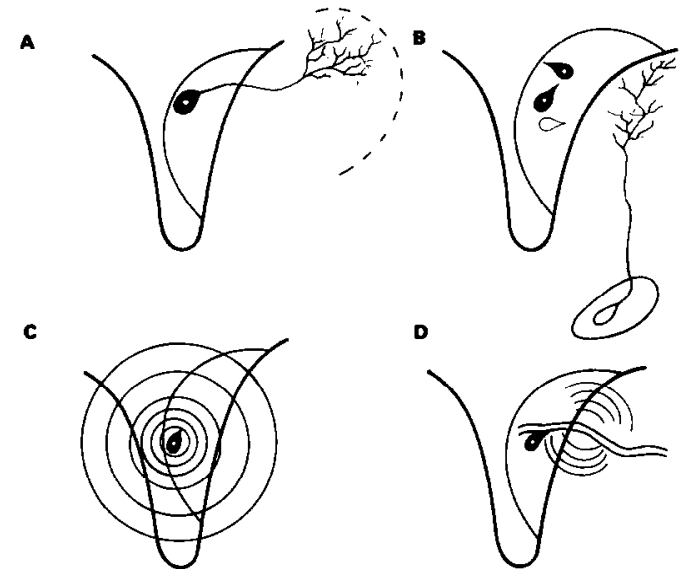

FIG. 4. Possible mechanisms of action of adrenal medulla grafts. (A) It is conceivable that transplanted adrenal chromaffin cells actually reinnervate host brain. This does not appear to occur in most circumstances; however, reinnervation of host brain has been suggested as a possible mechanism of action for chromaffin cells from immature rat donors (100). (B) A second possibility, recently suggested by Bohn and colleagues (19), is that adrenal medulla grafts promote the regrowth of host dopaminergic neurites. (C) It was initially suggested that intraventricular adrenal medulla grafts exert their behavioral effects by secreting catecholamines, which then reach the host brain through diffusion, i.e., a paracrine mode of action. This is not likely to be the mechanism of action of these grafts, because dopamine is not usually found in the ventricular CSF of animals with behavioral changes induced by adrenal medulla grafts (12). (D) Another possible mechanism of action (12) is that transplanted chromaffin cells secrete catecholamines into local blood vessels and that these catecholamines are then transported into the host brain through the circulatory system, i.e., an endocrine mode of action. These catecholamines may then leak out into the host brain through areas of increased blood vessel permeability adjacent to the graft (121).

this were the case, dopamine should be found in the CSF as well.

Although the absence of dopamine in the CSF of animals and humans with adrenal medulla grafts argues that diffusion probably does not mediate their effects, this mechanism should not as yet be entirely dismissed. First, it needs to be demonstrated that the diffuse release of small amounts of dopamine (e.g., from pumps or dopamine-releasing polymers) into the ventricle results in increased CSF dopamine. It is possible that small amounts of dopamine are rapidly diluted in CSF, making detection of increases difficult. Also, adrenal medulla grafts with large numbers of surviving cells cannot always be produced reliably, and it is possible that CSF dopamine would be increased when larger numbers of chromaffin cells survive. One study has, in fact, reported increases in CSF dopamine in human patients receiving intraparenchymal adrenal medulla grafts (75). Finally, increases in norepinephrine (about 3 -fold) and epinephrine (more than 20 fold) in spinal cord superfusate have been found in animals with adre- nal medulla grafts in the spinal cord (79). The increases in superfusate catecholamines were correlated with measures of alterations in pain perception. The possibility that adrenal medulla grafts release catecholamines into the interstitial space cannot yet, therefore, be entirely excluded.

\section{Blood Vessels and Blood-Brain Barrier Impairment}

Another possibility is that adrenal medulla grafts preserve their normal endocrine mode of action after transplantation and secrete dopamine not into the extracellular fluid but into blood vessels $(12,13)$. These blood vessels might then carry the secreted dopamine into the adjacent host brain. Rosenstein and Brightman have found that intracerebral tissue grafts in general produce local impairment of the blood-brain barrier $(122,123)$. Adrenal medulla grafts result in local permeability of the blood-brain barrier (121) and are associated with fenestrated capillaries (108). Sagen and Pappas (125) found an apparent partial permeability of

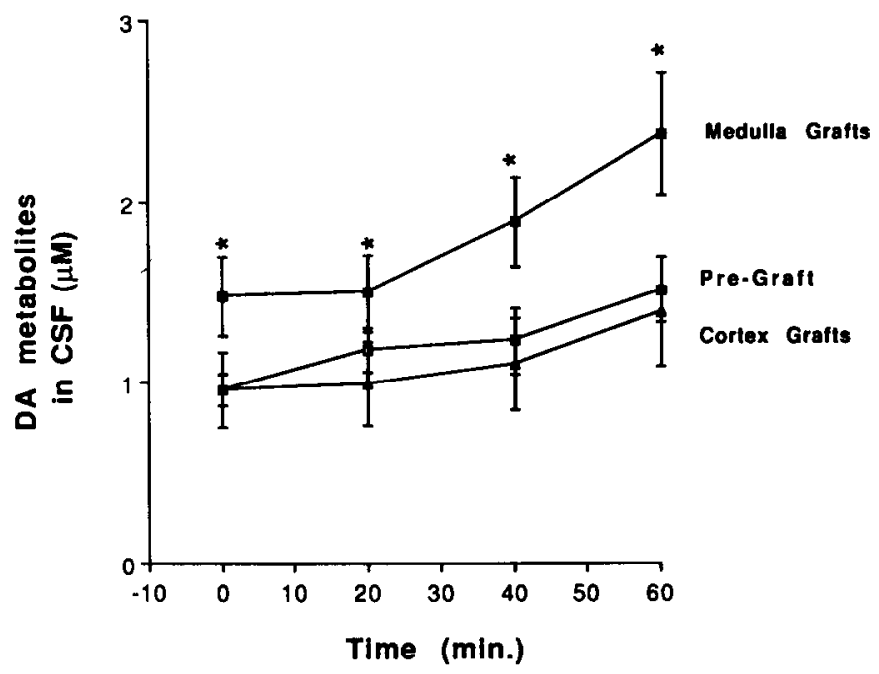

FIG. 5. Accumulation of dihydroxyphenylacetic acid (DOPAC) and homovanillic acid (HVA) in the CSF following probenecid treatment in animals prior to grafting (open squares; $N=17$ ), animals with adrenal cortex grafts (open triangles; $N=8$ ), and animals with adrenal medulla grafts (closed squares; $N=7$ ). Concentrations of DOPAC and HVA were determined from samples obtained using microdialysis in the lateral ventricle. Samples were collected over 20min intervals. Dialysate from the CSF was assayed by HPLC with electrochemical detection for dopamine, DOPAC, and HVA before and after acid hydrolysis. Values reported above are the total amount of DOPAC + HVA (free plus conjugated). No dopamine was detected. Baseline samples were obtained at Time 0 . Animals then received 200 $\mathrm{mg} / \mathrm{kg}$ probenecid to block the efflux of acidic metabolites from the CSF. Samples were collected at 20 -min intervals over the next hour. *Animals with adrenal medulla grafts had significantly higher $(P$ $<0.05)$ CSF concentrations of dopamine metabolites than animals with adrenal cortex grafts, or than the same animals before transplantation. Bars indicate standard errors of the mean. For additional details see Ref. (12). (Data are adapted from Ref. (12).) 


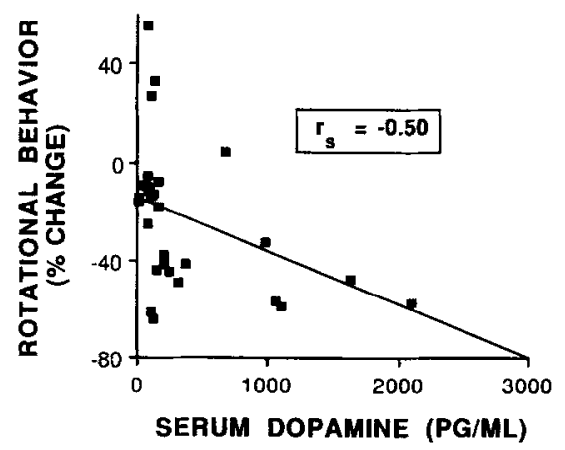

FIG. 6. Serum dopamine and rotational behavior. Correlation between serum dopamine concentrations and the change in rotational behavior produced by adrenal medulla grafts. Serum concentrations of dopamine $(\mathrm{ng} / \mathrm{ml})$ were correlated (Spearman's $\rho=-0.50$, $P<0.01$ ) with the decrease in apomorphine-induced rotational behavior following adrenal medulla grafts. The change in rotational behavior is expressed as a percentage of pregraft rotational behavior. Each square represents the data from one animal $(N=28$; data from Refs. (10) and (12) are combined).

the blood-brain barrier to pharmacological agents following adrenal medulla grafts, while Ahlskog et al. (1) found a partial permeability of the blood-brain barrier to carbidopa, but not to larger molecules, 6 months after adrenal medulla transplantation in human patients.

This blood-brain barrier impairment is thought to occur through two mechanisms: first, blood vessels in peripheral tissue grafts have a fenestrated endothelium characteristic of peripheral vessels. Second, leakiness of blood vessels may occur at the point of anastomosis between graft and host blood vessels $(122,123)$. It is interesting that intrastriatal pituitary tissue grafts have been found to cause leakage of the blood-brain barrier over a relatively wide area within the host striatum (27). If the grafted adrenal chromaffin cells secrete catecholamines into local blood vessels, these catecholamines might then leak out into the host brain at the point of anastomosis between graft and host vessels, within the corpus striatum of the host animal. In support of this hypothesis, it was found that peripheral blood of animals with adrenal medulla grafts contained increased amounts of dopamine, while blood epinephrine and norepinephrine were not increased $(10,11)$. Moreover, concentrations of dopamine in peripheral blood were directly correlated with the behavioral efficacy of these grafts, as measured by reductions in apomorphine-induced rotational behavior (12). The correlation of dopamine in blood with behavioral effects was replicated in a second experiment (Fig. 6) (Refs. (10, 11)).

Adrenalectomized animals also showed increases in blood dopamine after adrenal medulla grafts, but the increases in blood dopamine in the adrenalectomized animals were not correlated with the behavioral effects of the grafts $(11,12)$. There was no clear relationship between the number of surviving chromaffin cells and the increases in blood dopamine (the histology, however, was done some time after blood collection), so there is a possibility that the increased blood dopamine is not secreted by the transplanted cells. A peripheral source for the increased blood catecholamines cannot, therefore, be entirely ruled out. Further experiments to clarify this issue are in progress.

There is evidence that dopamine from the blood can enter the brain in animals with adrenal medulla grafts $(10,11,121)$. Following systemic injections of dopamine, we have found that extracellular dopamine is increased in brain areas adjacent to adrenal medulla grafts (10, 11). This apparent entry of dopamine from blood to brain was found in animals with behaviorally effective adrenal medulla grafts, but not in most animals for which the grafts were ineffective (11). It thus seems possible that graft survival is necessary for both behavioral efficacy and blood-brain barrier impairment in this model; moreover, surviving nonchromaffin cells (65) may be sufficient to produce blood-brain barrier permeability. Impairment of the blood-brain barrier may therefore play an important role in the effects of adrenal medulla grafts.

\section{B. Effects Not Dependent on Catecholamine Secretion}

\section{Possible Trophic Effects}

A number of recent studies suggest that adrenal medulla grafts may produce functional or anatomical effects that do not depend upon catecholamine secretion. In the first such experiment, Bohn and co-workers (19) reported that adrenal medulla grafts promote the reappearance of $\mathrm{TH}$ immunoreactivity in the striatum of mice with damage of the nigrostriatal dopaminergic neurons induced by the neurotoxic agent 1-methyl-4phenyl-1,2,3,6-tetrahydropyridine (MPTP). Under most circumstances MPTP does not destroy all nigral dopaminergic neurons, particularly in mice, but instead causes a temporary impairment of these cells resulting in decreased $\mathrm{TH}$ expression (62). These grafts therefore did not necessarily produce a regrowth of dopaminergic terminals per se, but may have accelerated the reappearance of TH immunoreactivity in terminals of damaged neurons. The grafts in this study were implanted into previously prepared cavities (lesion sites) in the cerebral cortex and very few catecholaminergic cells survived. The increased $\mathrm{TH}$ immunoreactivity was determined by comparing the side of the brain with grafts to the opposite, nongrafted side of the brain. Some animals in this study received sham grafts of gelfoam. No increase in TH immunoreactivity was seen in these animals, although these data were not shown. No animals received grafts of other control tissues. Functional effects of adrenal medulla grafts were not examined in 
this study, as the MPTP-treated mouse does not exhibit measurable functional deficits.

A second experiment by Bing and co-workers (15) also observed an apparent sprouting response, consisting of an increase in $\mathrm{TH}$-immunoreactive neurites surrounding grafts of adrenal chromaffin cells, and also glomus cells from the carotid body, into the striatal parenchyma. A smaller degree of sprouting-like response was seen in animals with PC-12 pheochromocytoma cell grafts. No recovery of $\mathrm{TH}$-immunoreactive fibers was produced by control injections of culture medium. Although fewer than 100 chromaffin cells survived transplantation in any of the animals, decreases in amphetamine-induced rotational behavior of more than $50 \%$ were seen after 3.5 weeks. This suggests that the sprouting-like response may have contributed to the decreases in rotational behavior. One factor that may have contributed to the observation of a sprouting-like response in this experiment, but not in several other studies using the 6OHDA lesion model $(45,49,114,146)$, is that the time interval between 60HDA lesions and transplantation was only 10 days, which could have permitted the grafts to prevent the subsequent death of damaged dopaminergic neurons (15). Other previous studies of adrenal medulla grafts employed time intervals between lesioning and transplantation of one to several months.

Subsequent studies of adrenal medulla grafts in primates using the MPTP model also suggest that adrenal medulla grafts promote the growth of catecholaminergic neurites adjacent to the grafts $(36,54)$. In these experiments grafts were implanted into cavities in the ventricular wall as well as directly into the head of the caudate nucleus. Both procedures enhanced $\mathrm{TH}$-immunoreactive fibers adjacent to the grafts, but implantation directly into the brain was the more effective procedure. It should also be noted that the MPTP lesions in these animals caused markedly decreased TH immunoreactivity in the $\mathrm{SN}$, but there did not appear to be a substantial loss of cell bodies. In this study (36), it was reported that the presence of enhanced $\mathrm{TH}$-immunoreactive fibers was not dependent upon implantation of tissue and was observed equally in one animal that received implantation of the metal tissue carrier without tissue. The illustrations (Fig. 4 in Ref. (36)) show that the enhancement of TH-immunoreactive fibers in the animal that received the metal tissue carrier alone was accompanied by intense $\mathrm{TH}$-like immunostaining of the ventricular ependyma, whereas the ependyma was unstained in the animals that received adrenal medulla grafts. The ependyma would not be expected to be positive for TH immunoreactivity. Thus, there did appear to be a substantial qualitative difference between adrenal medulla implantation and the tissue implantation procedure. One control received the tissue carrier only in the striatum, and another control received the tissue carrier in the ventricle. Enhanced staining was seen only in the control animal that received the tissue carrier implant into the striatum. These data do not entirely resolve the question of whether it is damage produced by surgery to the striatum alone that promotes the growth of $\mathrm{TH}$-immunoreactive neurites in adjacent areas or whether adrenal medulla implantation is required. Nevertheless, the fact that tissue implantation directly into the brain was more effective than intraventricular implantation in promoting $\mathrm{TH}$ immunoreactivity suggests that injury to the brain plays an important role in this response.

A recent study by Bankiewicz and co-workers (8) examined the effects of adrenal medulla grafts in rhesus monkeys with unilateral MPTP-induced nigrostriatal lesions. Animals received grafts of adrenal medulla, adrenal cortex, adipose tissue; sham operation; or lesion only. Animals were evaluated in terms of ipsi- or contralateral limb use and apomorphine-induced rotation. In terms of apomorphine-induced rotation, the adrenal medulla grafts produced a large (about $70 \%$ ) reduction in rotational behavior 3 months after transplantation, compared to approximately $30-40 \%$ for the adrenal cortex, adipose tissue, and sham groups, and no change for the lesion-only group (no statistics were given). Six months after transplantation, all three tissue groups (adrenal medulla, adrenal cortex, and adipose tissue) showed $30-40 \%$ decreases, while there were no decreases in the lesion-only and sham groups. Thus the adrenal medulla group produced effects greater than those of the other tissues at 3 months only. For the limb-use test, however, only the adrenal medulla group produced an improvement. This improvement was present at 3 months, but disappeared by 6 months. There were no changes in any of the other groups. Adrenal medulla, therefore, produced some specific effects, but these effects did not persist indefinitely. More modest, but longer lasting, nonspecific effects seem to have been associated with tissue implantation. Histologically, evidence of increased TH-immunoreactive neurites was found adjacent to tissue implantation sites. The increase in TH-immunoreactive neurites seen in the Bankiewicz et al. (8) and Fiandaca et al. (36) studies seemed to be somewhat more localized anatomically, compared to that reported by Bohn et al. (19). In the mouse, the increased $\mathrm{TH}$ immunoreactivity seemed to be relatively widespread, over large parts of the caudate-putamen (19), although this does not necessarily indicate a fundamental difference in the nature of the effect in view of the much larger size of the primate compared to that of the mouse striatum.

In the experiment by Bankiewicz and co-workers (8) it was reported that transplantation of tissue, including adrenal medulla, cortex, and adipose tissue, in addition to the creation of a surgical wound in the head of the 
caudate, caused equivalent fiber growth from intact dopamine neurons into the damaged caudate nucleus (p. 548). The functional improvement was attributed to the sprouting of TH-immunoreactive fibers. No behavioral changes were, however, seen in the sham-operated animals, either in terms of rotational behavior or limb use, 6 months after transplantation when the histology was done. Although it is not entirely clear, this study in fact suggests that the behavioral effects of these grafts were unrelated to the enhancement of TH immunoreactivity, since this enhanced TH immunoreactivity was apparently seen in the sham-operated animals 6 months after transplantation when these animals showed no behavioral improvement. This is essentially the only study in primates that attempted to correlate behavior and histology, and this study could easily be misinterpreted as indicating that the behavioral effects were due to the sprouting-like enhancement of $\mathrm{TH}$ immunoreactivity.

It is also noteworthy that any histological features responsible for the earlier improvements (at 3 months) in the adrenal medulla-grafted group would presumably not have been detected, since the histology was done after these effects had disappeared. It is also unusual that changes present at 3 months would disappear by 6 months after transplantation, because 3 months is a sufficient period of time for most transient phenomena, such as death of the transplanted cells, to dissipate. More complete evaluation of this study will, however, have to await publication of a more complete report. Another recent study by Bankiewicz and colleugues (7) reported behavioral improvement in primates receiving fetal SN grafts, which appeared to be related to sprouting of new TH-immunoreactive fibers from the ventral striatum. This conclusion was reached because these fetal brain grafts did not reinnervate the host brain (7), in contrast to the reinnervation seen in many other studies of fetal SN grafts (e.g., $(17,42,44,52,53,93,111,138)$ ).

In unpublished experiments (Freed, Poltorak, and H. E. Cannon-Spoor, unpublished observations), extensive TH-like immunoreactivity was frequently observed in areas adjacent to adrenal medulla allografts, particularly when the grafts were placed in the rat hippocampus. Large numbers of surviving cells were found in some grafts located in the hippocampal formation. The intrahippocampal grafts sometimes were associated with pronounced TH-like immunoreactivity in surrounding tissues. It has also previously been noted that diffuse $\mathrm{TH}$-like immunoreactivity is associated with intrastriatal pheochromocytoma cell grafts (51). This "nonspecific" diffuse immunoreactivity is suggestive of the gradual release of TH enzyme or its fragments from dead or damaged cells, followed by uptake into nearby cells or adherence to nearby tissues and, in some cases, retrograde transport to the cell soma. Although TH turns over quite rapidly (147), there could be continuous release of $\mathrm{TH}$ enzyme from dying transplanted cells. Occasional staining of hippocampal granule cells and fibers in animals with intrahippocampal adrenal medulla grafts (Fig. 7) could be an example of retrograde transport of $\mathrm{TH}$-immunoreactive material. Degradation products of the $\mathrm{TH}$ enzyme with preserved epitopes recognized by the polyclonal $\mathrm{TH}$ antibodies might also be responsible for this TH-like staining. Cross-reactive degradation products could adhere to extracellular matrix or damaged transplanted tissue. If this in fact occurs, it could account for some of the observations of enhanced TH immunoreactivity in fibers adjacent to adrenal medulla grafts, which has been interpreted as representing a trophic effect on the host brain.

In a recent report by Date and co-workers (26) that found a sprouting-like increase in TH immunoreactivity, an increase in dopamine concentrations was also found in the striatum adjacent to adrenal medulla grafts in MPTP-treated mice. The increases in TH expression and dopamine concentrations were greater in young mice compared to those in aging ( 1 year old) mice. In the aging mice, little or no increase in $\mathrm{TH}$ immunoreactivity and a smaller increase in striatal dopamine were seen. All mice received grafts from young donors, so the differences were due to the difference in the age of the host rather than to differences in donor age. Control animals in this study received sham operations in which the implantation needle was inserted into the striatum, but no tissue was implanted. Thus tissue injury may not have been responsible for the "trophic" effect, although implantation of tissue certainly results in greater injury and tissue reaction than a sham operation alone. It is also possible that dopamine produced by the graft contributed to the increases in striatal dopamine in this experiment (26), in view of the fact that some transplanted chromaffin cells survived.

Animals with unilateral SN lesions showed bilateral changes in striatal extracellular dopamine and dihydroxyphenylacetic acid (DOPAC) concentrations, determined by microdialysis in freely moving animals, after unilateral transplantation of adrenal medulla to the lateral ventricle $(10,11)$. These changes consisted of an increase in dopamine and DOPAC concentrations in the striatum ipsilateral to the grafts, in addition to a decrease in dopamine and DOPAC contralateral to the grafts $(10,11)$. The decreases on the contralateral, nongrafted side cannot easily be explained by direct effects of the grafts, and a complex effect involving the host brain must be invoked. One possibility is some "trophic" effect of the grafts, although it is also unclear how a trophic effect would produce one effect ipsilateral to the grafts and the opposite effect contralateral to the grafts. A second possibility is that the contralateral 

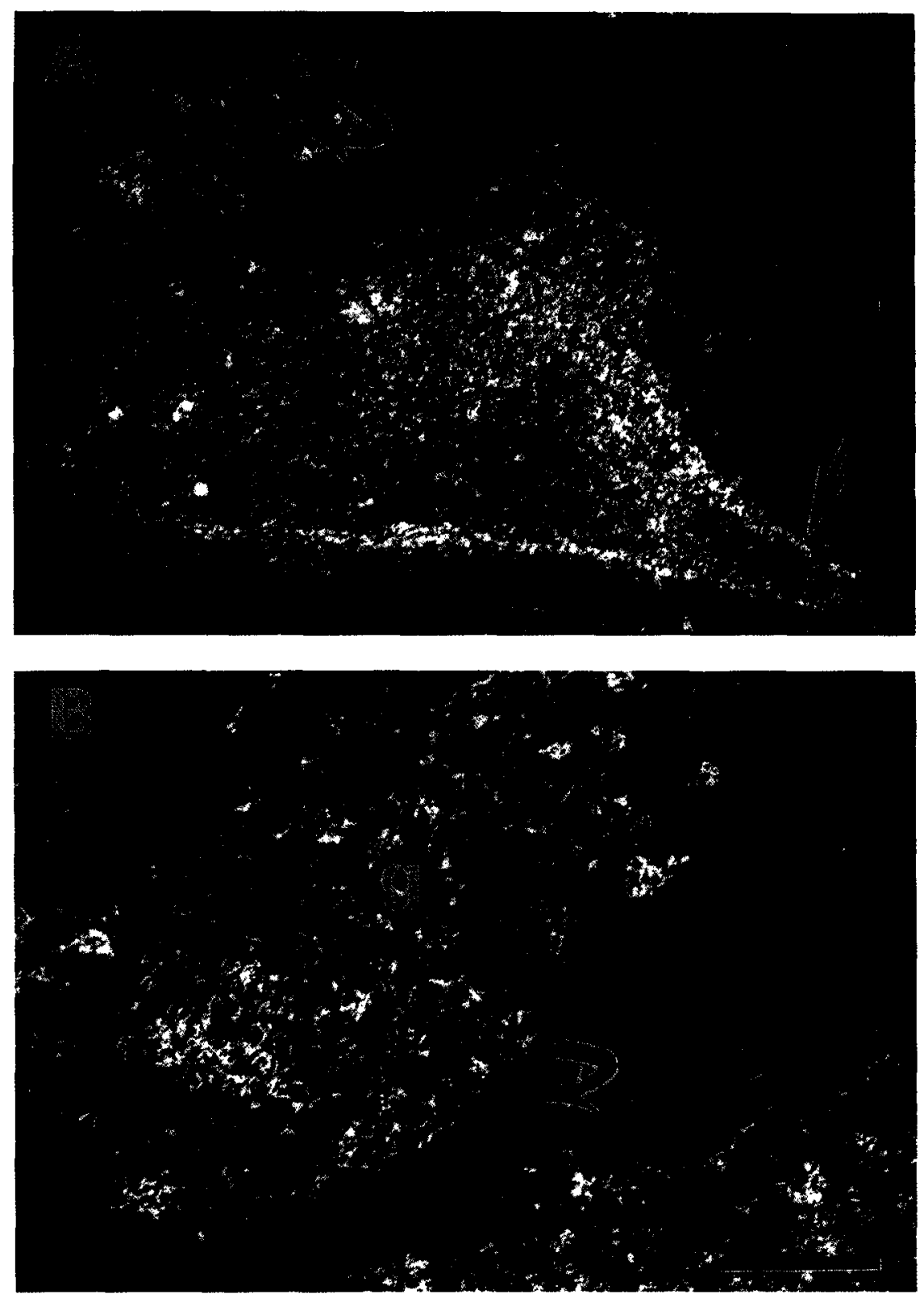

FIG. 7. An adrenal chromaffin cell allograft in the rat hippocampus. The donors were mature male Sprague-Dawley rats weighing between 400 and $420 \mathrm{~g}$, and grafts (consisting of one-half of an adrenal medulla) were implanted stereotaxically into the hippocampus at coordinates $3.0 \mathrm{~mm}$ posterior and $2.5 \mathrm{~mm}$ lateral to the bregma and $3.3 \mathrm{~mm}$ below the dura, with the bite bar $5.0 \mathrm{~mm}$ above the interaural line. This animal was euthanized 6 months after transplantation. Immunocytochemical staining by the peroxidase-antiperoxidase technique using an antibody provided by William Tank, University of Rochester, in a dilution of 1:3000 (dark-field). (A) TH immunoreactivity of an adrenal medulla graft in the hippocampus. A large group of transplanted chromaffin cells can be seen in the far upper left (bent arrow). Granule cells and their processes in the host brain (lower right and center; arrow) also appear to be stained. Calibration bar $=200 \mu m$. (B) Higher magnification of the transplanted chromaffin cells. Calibration bar $=80 \mu \mathrm{m}$.

changes are related to feedback mechanisms involving host brain circuits.

In summary, there appears to be either a specific trophic effect of adrenal medulla grafts or a nonspecific (injury-induced) trophic effect on striatal dopaminergic systems in MPTP-treated animals. Evidence for which of these two effects occurs remains incomplete. A trophic effect of brain injury on dopaminergic neurites, akin to the trophic effects of brain injury originally reported by Nieto-Sampedro and co-workers $(98,99)$ is certainly possible. Support for the operation of a similar brain injury-related trophic effect on dopaminergic neu- 
rites can also be derived from a report that cortical lesions enhance the outgrowth of neurites from intraventricular substantia nigra grafts (44). It is possible that these trophic effects contribute to the functional effects of adrenal medulla grafts.

\section{A Possible NGF-Dependent Effect}

A recent study by Pezzoli and co-workers (114) confirmed that intraventricular adrenal medulla grafts reduce rotational behavior in rats with unilateral lesions of the substantia nigra. The amount of reduction of apomorphine-induced rotation was on the order of $40 \%$, which is roughly consistent with our earlier report (49). Considerably greater effects were, however, produced when intraventricular infusions of NGF were combined with adrenal medulla grafts, confirming the results of Stromberg and co-workers $(105,146)$. A surprising finding was that NGF infusions were equally effective when combined with adipose tissue or sciatic nerve grafts. NGF infusions alone, not in combination with any graft, had no effect. As observed in other studies $(42,49)$, control tissues, in this case adipose tissue or sciatic nerve, had no effect when implanted alone. Thus all three tissues, adipose tissue, sciatic nerve, and adrenal medulla, produced similar reductions in rotation when combined with NGF infusions, even though only adrenal medulla was effective without NGF. In agreement with previous reports, adrenal medulla grafts were effective when transplanted into the lateral ventricle, but not when transplanted into the parenchyma of the corpus striatum.

There are several possible interpretations of these data. One, suggested by the authors, is that the exogenous NGF acts in concert with the reaction of the host brain to implanted tissue to produce a trophic effect on the CNS. Pezzoli et al. (114) used the 60HDA lesion model and no recovery of host dopaminergic terminals similar to that reported by Bohn and co-workers (19) was observed in their study. Other studies using similar 6OHDA lesion models also have not observed anatomical recovery of dopaminergic terminals $(49,146)$. Nevertheless, these grafts could induce trophic effects other than regrowth of dopaminergic neurites. Other possible explanations include impairment of the blood-brain barrier (121-123), interactions between the intracerebral NGF injections and the sympathetic system (84, 85 ), alterations in blood catecholamine concentrations, or effects produced by fibroblasts included in the grafts $(65,66)$. Although the mechanism of action of adrenal medulla grafts and NGF infusions in experimental Parkinson's disease models is unclear, these data cast additional doubt upon the simplistic notion that dopaminergic mechanisms are entirely responsible for the functional effects of adrenal medulla grafts.

\section{Comments and Questions Regarding Possible Trophic Effects of Adrenal Medulla Grafts}

a. Are the effects produced by adrenal medulla grafts or by nonspecific damage? A demonstration that trophic effects of adrenal medulla grafts are specific for adrenal medulla, as opposed to a nonspecific damage effect, would of course require a comparison with a control group receiving control grafts that produce equivalent damage. On the basis of the discussion above (section IV B 1), it is not possible to conclude that at least this particular trophic effect (enhancement of TH immunoreactivity in the MPTP-lesioned animal) is specific for adrenal medulla grafts. On the other hand, there are substantial indications that enhanced TH immunoreactivity can occur in areas adjacent to either adrenal medulla grafts or nonspecific tissue damage. To what degree this effect contributes to the functional effects of surviving adrenal medulla grafts remains unclear.

$b$. With what lesion models are these trophic effects observed? Most of the studies in which adrenal medulla grafts have been reported to have trophic effects have used the MPTP lesion model, in either mice $(19,26)$ or primates $(8,36)$. In this model system, damage to the $\mathrm{SN}$ dopaminergic neurons resulting in decreased $\mathrm{TH}$ expression appears to occur without necessarily being accompanied by death of all nigral dopaminergic cells $(62,119)$, whereas 60 HDA as generally used permanently destroys the dopaminergic neurons. Thus it is possible that adrenal medulla grafts somehow promote recovery of these damaged cells, resulting in a more rapid reexpression of the $\mathrm{TH}$ protein.

In the majority of studies of adrenal medulla grafts using the 60HDA lesion model, where the SN neurons are permanently destroyed, similar trophic effects have not been observed. There are, however, a few exceptions including studies by Bing et al. $(15,55)$ (cf. section IV B 1), Brown and Dunnett (20), and Pezzoli et al. (114). The latter two experiments $(20,114)$ did not report increased TH immunoreactivity in the host brain, although smaller increases in TH expression that were not detected or other kinds of trophic effects are possible. Thus some trophic effects of adrenal medulla grafts other than diffuse dopamine release may also occur in the 6OHDA-lesioned rat model.

An important question, which is beyond the scope of this paper, is which of the two models, MPTP- or 60HDA-induced damage, is more relevant to the clinical phenomenon of Parkinson's disease. Ultimately, in Parkinson's disease SN neurons are irrevocably lost, which is not always the case for MPTP-treated animals. On the other hand, the loss is probably gradual, unlike the sudden destruction of neurons in the 60HDA model. Notwithstanding, there is some evidence for trophic effects of adrenal medulla grafts in clinical situa- 
tions. The disappearance of a dopamine neuron-staining antibody from the CSF of patients receiving adrenal medulla grafts is most readily explained as a trophic effect (95). Hirsch and co-workers (71) have also observed a sprouting-like enhancement of $\mathrm{TH}$ immunoreactivity adjacent to an adrenal medulla graft in a human postmortem tissue sample.

\section{Possible Mechanisms for Induction of a Specific Trophic Effect}

It is somewhat difficult to conjecture on the mechanisms for the induction of trophic effects, since it is not yet known whether these effects are related to adrenal medulla implantation or to nonspecific damage. One likely possibility, at this point, seems to be that nonspecific tissue implantation produces a certain amount of enhanced TH immunoreactivity, but implantation of any tissue (e.g., sciatic nerve, adipose tissue, adrenal medulla) greatly enhances the effect. This would be consistent with an intriguing possibility, suggested by several authors $(19,36,65,114,120)$, that the macrophage/microglial and astrocytic reaction to the implantation is responsible. The fact that tissue implantation would be expected to result in a host response greater than that of the surgical procedure alone would be consistent with this possibility. It has been pointed out that macrophages and brain microglia release a number of substances, including interleukin-1 $(3,39,56,86)$. Therefore, if the surgical procedure produces a small trophic response but tissue implantation enhances this response, it would be consistent with the possibility that the putative trophic response to adrenal medulla grafts is related to a host reaction to tissue implantation.

If, on the other hand, adrenal medulla grafts do indeed have a specific trophic effect upon host brain (as opposed to a nonspecific injury effect), then a mechanism to account for this effect would have to be found. Several possibilities have so far been suggested. One is the possible involvement of a dopamine-releasing factor that is present in the adrenal medulla (23). A second possibility, suggested by Otto and Unsicker (107), is that basic fibroblast growth factor (bFGF) produced by the adrenal medulla is responsible. Blottner and associates (18) found that bFGF is present in adrenal medulla. Otto and Unsicker (107) administered bFGF, in gelfoam implants, into the striatum of mice that had been treated with MPTP, using a model similar to that used by Bohn et al. (19). The bFGF implants increased TH mRNA, TH catalytic activity, and catecholamine concentrations in the striatum. Increases in $\mathrm{TH}$ activity were seen both ipsilateral and contralateral to the implant, but the increases were greater on the ipsilateral side. Ipsilateral to the bFGF implant, the TH mRNA was increased, while contralateral to the implant $\mathrm{TH}$ activity was increased without a change in mRNA levels.

Another possibility $(116,117)$ is that cell adhesion molecules or extracellular matrix components may be responsible for some of the effects of adrenal medulla grafts. Certain cell adhesion molecules (CAMs) are involved in the molecular mechanisms of contact between cells and extracellular matrix components $(35,133)$. The L2/HNK-1 family of cell adhesion molecules is defined by a common carbohydrate epitope recognized by the L2 and HNK-1 monoclonal antibodies; this family includes the L1/Ng-CAM, N-CAM, J1/tenascin, and myelin-associated glycoprotein molecules (133). Adrenal medulla contains most of the CAMs from the L2/ HNK-1 family, and NGF stimulation increases expression of both L1/Ng-CAM and N-CAM on chromaffin cells in vitro (117). After transplantation to the lateral cerebral ventricle, there was a pronounced increase in the expression of $\mathrm{L} 1 / \mathrm{Ng}$-CAM and a marked decrease in $\mathrm{J} 1$ /tenascin immunoreactivity. N-CAM was also present in adrenal medulla after transplantation, but was primarily seen on extracellular matrix fibers. Laminin immunoreactivity was also increased in adrenal medulla after transplantation. In this experiment (116) most adrenal medulla grafts survived but a minority of grafts, particularly those misplaced within the brain parenchyma, were found to have degenerated. These degenerated grafts showed decreased $\mathrm{J} 1 /$ tenascin, laminin, N-CAM, and L1/Ng-CAM immunoreactivity. Development of immature dopaminergic neurons has been found to be stimulated by both an insoluble membrane-bound component $(69,118)$ and a soluble extract $(25,152)$ from striatum. If cell adhesion molecules are involved in the effects of adrenal medulla grafts, they could account for some of the positive effects obtained with other tissues, such as sciatic nerve and adipose tissue $(8,114)$. We are currently attempting to determine whether one of the CAMs or extracellular matrix components present in adrenal medulla has a stimulatory effect on the growth of dopaminergic neurites.

\section{Conclusions from Basic Studies and Comments}

At the present time, the mechanism of action of adrenal medulla grafts is very much in doubt. As discussed above, studies of the trophic effect of adrenal medulla grafts in increasing TH immunoreactivity have not provided conclusive evidence that these effects are specific. Quantitative data comparing adrenal medulla grafts with controls receiving various other tissue implants are also not yet available. Few studies have examined the possibility that this trophic effect is associated with any kind of functional or behavioral recovery. A second type of NGF-dependent trophic effect, reported in the experiment by Pezzoli et al. (114), although dependent upon tissue implantation, was not specific for adrenal me- 
dulla and the anatomical or biochemical basis for this effect is not yet known.

Regarding dopamine-release theories of the effect of adrenal medulla grafts, evidence is also lacking. No consistent relationship between the number of surviving transplanted chromaffin cells and behavioral effects has been found, and there is no increase in dopamine in the CSF of animals with adrenal medulla grafts. In one study, by Decombe and co-workers (27) there was a very clear correspondence between graft survival and a nicotine-induced behavioral effect, but in this study the grafts did not decrease amphetamine- or apomorphineinduced rotational behavior. A variant of this hypothesis, that adrenal medulla grafts deliver dopamine into the host brain via blood vessels, is supported by a correlation between blood dopamine and behavioral effects of adrenal medulla grafts (12). It must, however, be pointed out that this study did not contain a transplanted control group, and it is therefore not certain either that this dopamine found in blood actually was derived from the grafts or that the effect was specific for adrenal medulla grafts.

It is quite possible that adrenal medulla grafts induce functional recovery in the 60HDA-lesioned rat model by two or more independent mechanisms, perhaps including a direct dopamine-mediated effect in addition to a trophic effect on host brain. This would be consistent with the observation that the effects of adrenal medulla grafts on amphetamine- and apomorphine-induced rotational behavior were dissociable (10). In other words, some animals showed a decrease in response to amphetamine, others showed a decrease in response to apomorphine, and others showed both decreased amphetamine- and apomorphine-induced turning. It is also possible that increased serum or brain dopamine in animals with adrenal medulla grafts, in addition to acting directly upon the host brain, may be taken up and utilized by the few remaining host dopaminergic neurons (10).

Regarding these as well as all other hypotheses of adrenal medulla graft function, it should nevertheless be emphasized that adrenal medulla grafts have not been convincingly demonstrated to exert a specific trophic effect on host brain, nor have the changes in blood catecholamines been shown to be a direct result of catecholamine secretion from the transplanted adrenal chromaffin cells. Moreover, even other possibilities, including diffuse secretion of catecholamines or other substances such as endorphins $(9,30,124,131)$, have not entirely been ruled out.

There is a fundamental methodological problem that has contributed to much of this confusion. It is difficult to perform experiments to determine how adrenal medulla grafts function, when survival of the grafts does not occur consistently. In several experiments, functional effects of adrenal medulla "grafts" have been found, even though the chromaffin cells largely did not survive $(8,15,20)$. Under these circumstances, effects that require chromaffin cell survival would, of course, not be seen. Although intracerebral adrenal medulla grafts certainly are capable of surviving, the factors that are important for the survival of intracerebrally transplanted adrenal chromaffin cells are not well understood. Added NGF can increase graft survival (144, 146), but additional factors certainly exist. Until it becomes clear how to obtain consistent adrenal chromaffin cell graft survival without added NGF, it will be difficult to resolve the mechanisms of action of these grafts.

\section{ADRENAL MEDULLA GRAFTS IN PRIMATES}

In primates, there have been several studies of embryonic substantia nigra grafts (e.g., (138)), but relatively little attention has been paid to adrenal medulla grafts. Morihisa and co-workers (96) found a very limited survival of intrastriatal adrenal medulla grafts. No surviving intraventricular adrenal medulla grafts were found. Hansen and co-workers (65) found a very limited survival of chromaffin cells in adrenal medulla grafts implanted into the striatum using a metal tissue carrier or implanted into the ventricular wall. The only other published study of adrenal medulla grafts in primates was that of Bankiewicz et al. (8) described above. No surviving chromaffin cells were found in that study. Recently, however, Dubach and German (31) reported on a surgical technique for adrenal medulla graft implantation in primates that avoids ejection of the implanted tissue by application of pressure, and increases contact between the graft and host brain by ejecting the adrenal medulla tissue into the host brain as elongated tissue ribbons. This method resulted in increased chromaffin cell survival, and when combined with NGF infusions large numbers of adrenal chromaffin cells were found to survive intrastriatal implantation. Wyatt and co-workers (166) also reported on an implantation device that avoids application of pressure to the tissue which resulted in increased survival of chromaffin cell grafts in primates in some cases. A second method for adrenal medulla transplantation in primates, involving combination of adrenal medulla grafts with segments of sural nerve, also results in excellent cell survival (64). A preliminary report of a trial of adrenal medulla transplantation in primates using the Madrazo et al. (90) surgical technique has appeared, and in general some limited survival of chromaffin cells and behavioral improvement were observed (6).

\section{CLINICAL TRIALS OF ADRENAL MEDULLA GRAFTS IN PARKINSON'S DISEASE}

\section{A. Examination of Clinical Studies}

There have been several attempts to employ adrenal medulla transplantation in patients with Parkinson's 
TABLE 1

Clinical Trials of Adrenal Medulla Transplantation for Parkinson's Disease

\begin{tabular}{|c|c|c|c|c|}
\hline Investigators & Method & $\begin{array}{l}\text { Number of } \\
\text { subjects }^{a}\end{array}$ & Assessment methods & General outcome \\
\hline Backlund et al. (4) & $\begin{array}{l}\text { Stereotaxic into } \\
\text { caudate } n .\end{array}$ & 2 & Chart review & $\begin{array}{l}\text { Short-term improvement } \\
\text { (days) }\end{array}$ \\
\hline Lindvall et al. (87) & $\begin{array}{l}\text { Stereotaxic into } \\
\text { putamen }\end{array}$ & 2 & Quantitative tests & $\begin{array}{l}\text { Temporary improvement } \\
\text { (weeks) }\end{array}$ \\
\hline Madrazo et al. (90) & Ventricular wall & $2^{b}$ & Subjective ratings & Long-term improvement \\
\hline $\begin{array}{l}\text { Drucker-Colin et } \\
\text { al. }(30)\end{array}$ & & $11^{b}$ & $\begin{array}{l}\text { Electromyograms } \\
\text { Spectrophotograms }\end{array}$ & developing over months \\
\hline $\begin{array}{l}\text { Ostrosky-Solis et } \\
\text { al. }(106)\end{array}$ & Ventricular wall & $7^{b}$ & Neuropsychological tests & Long-term improvement \\
\hline Jiao et al. $(74,75)$ & $\begin{array}{l}\text { Stereotaxic into } \\
\text { caudate n. }\end{array}$ & 10 & Rating scales & Long-term improvement \\
\hline Goetz et al. $(58,60)$ & Ventricular wall & 19 & $\begin{array}{l}\text { Rating scales } \\
\text { Self-assessments }\end{array}$ & $\begin{array}{l}\text { Mixed long-term } \\
\text { improvement }\end{array}$ \\
\hline Kelly et al. (78) & Ventricular wall & 7 & Rating scales & Slight improvement ${ }^{d}$ \\
\hline Allen et al. (2) & $\begin{array}{l}\text { Ventricular wall } \\
\text { w/thrombin, etc. }\end{array}$ & 17 & Columbia rating scale & Slight improvement ${ }^{d}$ \\
\hline Jankovic et al. (73) & Ventricular wall & 3 & Rating scales & Modest improvement ${ }^{d}$ \\
\hline
\end{tabular}

${ }^{a}$ Including only those patients for which outcome should be measured; patients that died or did not recover from surgery were not included.

b These three reports describe some of the same patients.

${ }^{c}$ Photographic recordings of movements

${ }^{d}$ More substantial improvement was reported in some of the subjects.

disease (Table 1). Two primary different autotransplantation methods have been used, with some minor variations. The first, initially carried out by Backlund and colleagues (4) at the Karolinska Institute and more recently reported by Lindvall and co-workers (87) involves transplantation of adrenal medulla directly into the striatum by stereotaxic injection. The second technique, developed by Madrazo, Drucker-Colin, and their colleagues (90) at the Universidad Nacional Autonoma de Mexico in Mexico City, involves transplantation of autologous adrenal medulla to cavities in the wall of the lateral ventricle, with the use of steel clips or other methods to anchor the tissue in place. Notwithstanding the technical modifications that were required to render these techniques applicable to human patients, these transplantation methods correspond in general to the intrastriatal and intraventricular adrenal medulla transplantation methods that had been developed in animals $(45,49,96,146)$.

Because it is impossible to perform control surgical procedures in human subjects it is correspondingly difficult to be certain about the efficacy of these procedures, and it is particularly difficult to rule out lesion effects as the cause of any improvements. Conversely, as operated patients have not generally been compared to nonoperated patients, or to any sort of control group, any effect of the grafts in slowing the rate of progression of the disease would also not be detected. Nevertheless, some tentative conclusions can be made. First, trans- plantation of adrenal medulla directly into either the caudate or putamen $(4,87)$ was not effective on a longterm basis. Improvements were noted over the first 1 week to 2 months after transplantation, but these improvements were transient and the patients reverted to their pretransplantation condition over the long term. In the latter study (87), thorough quantitative neurological assessments were employed. A total of only four patients was, however, examined, two in each $(4,87)$ study. As yet, there have not been any reports of intrastriatal adrenal medulla grafts in human patients in combination with NGF.

One additional report on intrastriatal adrenal medulla grafts, however, warrants comment. Jiao and coworkers $(74,75)$ at the Capital Institute of Medicine, in Beijing, People's Republic of China, transplanted adrenal medulla into the caudate nucleus, using a stereotaxic technique, in 10 patients. Modest to marked longterm improvement in their symptoms was reported. Although the assessment techniques were not as objective as those used in the more recent trial of intrastriatal grafts by Lindvall et al. (87), the possibility that their procedures were in some way superior to those employed in previous trials must at least be entertained. There were some differences between this trial and the previous intrastriatal adrenal medulla transplantation trials that could be significant: (i) more tissue was implanted; (ii) the time between adrenal medulla removal and reimplantation was very brief, between 5 and 15 
min; and (iii) L-DOPA administration was avoided after transplantation, and following the surgery only amantadine was used. In our experience, maintaining short time intervals between adrenal medulla removal and implantation seems to be important (unpublished observations). L-DOPA has also been reported to impair the survival of intracerebral embryonic brain tissue grafts (140), so that administration of L-DOPA might conceivably be a significant factor.

Tanner and colleagues (148) have also pointed out that there is a substantial difference between the usual treatment of patients with Parkinson's disease in China and the United States that could account for some differences in interpretation of changes following transplantation. In China, it is customary to treat Parkinson's disease with amantadine, trihexyphenidyl, and only very small dosages of $L$-DOPA. In this context, an improvement termed "excellent" in China might be considered relatively modest in the United States. 'Tanner and colleagues (148) felt that the improvement seen in the patients of Jiao et al. $(74,75)$ was very similar to the improvement observed in their own studies $(58,162)$ of adrenal medulla transplantation in Parkinson's disease patients. This would not, of course, explain the difference between the short duration of improvement seen by Backlund et al. (4) and Lindvall et al. (87) compared to the longer-lasting effects reported by Jiao et $a l$. $(74,75)$.

Autologous transplantation of adrenal medulla to the wall of the lateral ventricle, on the other hand, hus been reported to produce detectable long-term improvement in Parkinson's disease. The first report of this procedure (90) found a gradual long-term improvement in two very young patients with severe Parkinson's disease. Substantial improvement in larger groups of patients subjected to the same procedure has also been reported $(30,91)$. Because of the profound implications that success of this procedure would have, the data reported in these and related experiments will be examined in detail.

Considerable questions have been raised about interpretation of the changes that were reported $(90,91)$, in part because of the subjective nature of the clinical assessments, involving changes in ratings of general clinical status on a 0 to 6 scale. Large changes, from an average rating of 1.6 to an average rating of 4.5 , with half of the patients improving by 3 rating points or more, were reported (91). A second report, which apparently described the same patients, gave baseline ratings for 6 of the 10 patients and post-transplantation ratings for 7 of the 10 patients that differed slightly from those given in the earlier report (30). Also, when 1 patient, who had been reported as showing an improvement from 1 to 5 (91) came to autopsy, no surviving chromaffin cells were found (113). In the opinion of his family, there appeared to have been little improvement in the clinical status of this patient except during 2 weeks after the surgery. Of course, a clinical assessment provided by the family, that had recently lost a relative, might not be entirely accurate. This patient was the oldest in the series studied by Madrazo and co-workers (91) and suffered from dementia. The subsequent report (30) stated that older patients did relatively poorly after transplantation (91).

A more systematic follow-up study by the same group reported on neuropsychological changes and immediate postoperative effects of these grafts (106). Alleviation of motor deficits was noted during the first week following surgery, similar to the immediate postoperative improvement noted by Backlund and colleagues (4) for intraparenchymal grafts. Two other postoperative effects that were noted were (i) visual hallucinations, seen in 5 of the 7 patients during the first 3 days, and (ii) stereotyped or perseverative motor and verbal behavior, and reduced spontaneous language, for 15-20 days. Gradual amelioration of the predominant motor signs of the illness, beginning about 4 weeks after transplantation, was described. Neuropsychological testing revealed improvements in motor functions, somatosensory performance (e.g., tactile identification of shapes), visual recognition tasks, and certain memory tasks. Other measures, such as language, calculations, and most memory tasks, were unchanged (106). A subsequent examination of neuropsychological test profiles in a group of 11 patients did not show a significant change from before to after transplantation, although there continued to be a modest trend toward improvement (30).

Notwithstanding the discrepancies concerning interpretation of the changes reported by Madrazo and coworkers $(30,90,91)$, the claim that adrenal medulla grafts can cause a lasting and detectable clinical improvement in Parkinson's disease has essentially been independently replicated $(58,60)$. In a collaborative study by Goetz and colleagues ((58), also cf. (110)) adrenal medulla was autologously transplanted to the wall of the right lateral ventricle using exactly the Madrazo et al. (90) procedure. Nineteen patients were involved in the study, conducted at the University of Kansas, the University of South Florida, and Rush-Presbyterian-St. Luke's Medical Center. Clinical changes were assessed systematically, by objective rating scales. The improvements seen in this patient group were not as marked as those reported by Madrazo and colleagues; nevertheless, a number of significant changes were found. There were no significant changes in medication dosages from before to after transplantation. There were also no changes in measures of severity during "on" time periods. For "off" times, there were significant improvements according to the Unified Parkinson's Disease Scale, for the Activities of Daily Living subscale but not 
for the motor function subscale. The Schwab and England scale detected a substantial improvement, whereas there was no change by the Hoehn and Yahr scale. Neither scale detected changes in severity during the on periods. The mean age of the patients at the time of surgery was 54 years, and it was stated that the seven patients with the most marked improvement did not differ from the rest of the group in their age at surgery. Thus, even though these patients (58) were older than those studied by Madrazo et al. (90), the difference in age of the patients would not seem to account for the difference in the results.

Despite these equivocal results regarding severity of symptoms, there was a marked change in the duration of on and off times: The mean on time duration, as a percentage of the waking day, increased from $48 \%$ prior to surgery to $75 \% 6$ months after surgery, a significant change. The on time without chorea, also as a percentage of the waking day, was more than doubled from $27 \%$ before surgery to $59 \%$ after 6 months. This average degree of improvement in on durations is similar to the change that has been reported in the best single case of fetal brain tissue transplantation in a human patient reported thus far (88). There appeared to be an improvement from 1 to 3 months after surgery, but no additional improvement between 3 and 6 months. Results from the American Association of Neurological Surgeons and United Parkinson Foundation registries $(5,59)$, which compiled the results of several clinical trials employing the Madrazo technique, generally were consistent with the report of Goetz et al. (58). A recent report (60) found that the clinical improvement persisted for 1 year after surgery.

In general, the studies by Goetz and co-workers (58, $60)$ have confirmed that adrenal medulla grafts can result in measurable clinical changes, although there seem to be large differences in the degree of improvement reported in the various studies. The Madrazo et al. (90) study reported a dramatic improvement in the general status of the patients, whereas the studies of Goetz and co-workers $(58,60)$ reported more modest improvements. One possible explanation for some part of this difference, at least from the data that were published, is that the measures of outcome used in the two studies were much different. The Goetz et al. (58) study measured on and off times separately, whereas the Madrazo et al. (90) study made no attempt to systematically separate on and off times (also cf. (30)). In the Goetz et al. (58) study, the patients spent, on the average, only a small fraction of each waking day $(27 \%)$ in optimally useful (i.e., non-chorea) on time prior to transplantation, but after transplantation more than half of each day, on the average, was occupied with non-chorea on time (59-61\%). Thus, if patients were observed at random times without regard to whether they were in on or off states, the chances of observing and reporting each patient during an on phase would have been small prior to transplantation, but much greater (more than 50\%) subsequent to surgery. This (combined with the other improvements that were noted) could easily have led Goetz and co-workers $(58,60)$ to conclude that there had been a very substantial improvement if they had evaluated their patients in the same manner as $\mathrm{Ma}$ drazo et al. (90). In other words, if patients were observed randomly, most of the pretransplantation observations would be during off phases or on phases with chorea, while more than half of the post-transplantation observations would be during non-chorea on phases, resulting in the pre- versus post-transplantation difference consisting mostly of off versus on comparisons. Thus, it is possible that Madrazo et al. (90) were at least partially observing differences between on and off phases.

Is it possible to reach any objective conclusion regarding the degree of change found by Goetz and coworkers? That is, were these changes small, as it would appear from the rating scales, or of a useful clinical magnitude? To better understand this issue, we have derived, from the data of Goetz and co-workers $(58,60)$, a total function score (TFS) which is intended to assess the total level of functioning as a percentage of normal function, determined from the Schwab and England scores and percentages of the day in on and off states. The Schwab and England scores are expressed on a 1 to 100 scale, with the maximum score of 100 representing essentially normal or independent functioning (134). It must be noted that these scores are somewhat subjective and that the scale is probably not arithmetically linear. Levels of functioning are different during on and off periods, and since the amounts of on and off times were also changed, the TFS was derived by multiplying the Schwab and England score for on and off periods by the fraction of each day spent in each state, respectively (Table 2). Thus the TFS represents the total weighted average level of functioning during the course of each day, with $100 \%$ representing normal, unimpaired function.

Calculation of TFS values for the studies of Goetz and colleagues $(58,60)$ showed that the patients experienced approximately 20 to $30 \%$ increases in TFS scores from baseline (pretransplantation) levels by 3-6 months after transplantation. Approximately the same level of improvement was sustained for 1 year after transplantation (Table 2). This represents approximately a 50\% improvement; that is, $50 \%$ of the baseline deficit in motor function had disappeared. This would not seem to be a trivial change. Most of the difference, of course, results from an increase in the amount of each day in on time. In fact, on time without chorea was increased to an even greater degree, and if this factor were taken into 


\section{TABLE 2}

Calculation of "Total Function Scores" from the Data of Goetz and Co-workers $(58,60)$ using the Schwab and England Scale $(134)^{a}$

\begin{tabular}{llllll} 
State $\quad$ AmtOn $^{b}$ & $\begin{array}{l}\text { ROn } \\
(\%)\end{array}$ & AmtOff & ROff & $\begin{array}{l}\text { TFS } \\
(\%)^{c}\end{array}$ & $\begin{array}{l}\text { Percent } \\
\text { Improved }^{d}\end{array}$ \\
\hline
\end{tabular}

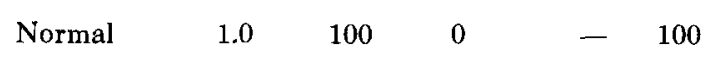

Data from Goetz and co-workers (58)

$\begin{array}{lllllll}\text { Baseline } & 0.48 & 67.1 & 0.52 & 16.7 & 40.7 & - \\ \text { 1 Month } & 0.55 & 70.0 & 0.45 & 40.3 & 56.5 & 27 \\ \text { 3 Months } & 0.78 & 73.7 & 0.22 & 57.9 & 70.2 & 50 \\ \text { 6 Months } & 0.75 & 71.8 & 0.25 & 53.2 & 67.2 & 15\end{array}$

Data from Goetz and co-workers (60)

\begin{tabular}{lllllll} 
Baseline & 0.61 & 83.3 & 0.39 & 33.6 & 63.7 & - \\
6 Months & 0.83 & 85.7 & 0.17 & 65.0 & 82.3 & 51 \\
12 Months & 0.83 & 86.3 & 0.17 & 59.7 & 81.7 & 50 \\
\hline
\end{tabular}

${ }^{a}$ Schwab and England scale: possible range $=0-100 \% ; 100 \%$ $=$ normal functioning. Note that the relationship between these scores and actual clinical status may not be linear. Ratings were obtained separately during on and off periods and the percentage of the waking day in on and off was also measured. The amount of the waking day in each state is expressed as a fraction; i.e., $10 \%=0.1$.

${ }^{b}$ Symbols used: amount of on time, AmtOn; amount of off time, AmtOff; rating during on time, ROn; rating during off time, ROff; total functioning score, TFS.

${ }^{c}$ Formula for calculation of total function score: TFS $=($ AmtOn $\times$ ROn $)+($ AmtOff $\times$ ROff $)$.

${ }^{d}$ Percentage improvement from before to after transplantation. A change in the TFS (total functioning score) from the appropriate baseline level to $100 \%$ would be an improvement of $100 \%$.

account, the amount of improvement would be larger than $50 \%$. It should also be noted that the average percentage improvement claimed by Drucker-Colin and coworkers (30) was $60.5 \%$. On the other hand, these percentage improvements in TFS do not consider the mortality; postoperative impairments, including hallucinations and other psychological manifestations; and various other adverse effects that have been seen $(60$, $73,106)$.

Goetz and his colleagues (58) concluded that production of dopamine by the transplanted cells could not readily explain the bilateral changes that were observed. It is, however, apparent that the changes observed were more "global" than "bilateral." A conclusion that changes were bilateral would require a separate measurement of motor function on each side. In other words, changes in on times or overall symptom severity do not necessarily reflect the laterality of any alterations. True measurements of laterality require measurements of motor function (such as finger tapping speed or pronation-supination) separately on each side. In the subsequent report (60) finger tapping and peg- board manipulation were separately measured for each side, and the improvements appeared to be similar for right and left. This test was done during on phases only. It is also possible that laterality changes would be better detected during off phases, as there generally were no changes in symptom severity during the on phases. The only other study of adrenal medulla grafts that addressed laterality specifically, in fact, was the earlier study of intrastriatal adrenal medulla grafts by Lindvall and colleagues (87). This study did detect short-term global changes, such as alterations in on times, even though more specific tests of motor function showed that the effects were clearly unilateral. Thus, the study of Goetz et al. (58) does not necessarily refute the hypothesis that the clinical effects of adrenal medulla grafts are related to local dopamine release or to other localized effects.

Several additional studies have recently reported on clinical trials of adrenal medulla transplantation in Parkinson's disease $(2,5,38,59,73,78,162)$. In one recent study by Kelly and co-workers (78) mild to moderate improvement in symptom severity was found, although one patient appeared to improve markedly. Strikingly, however, there were small but significant improvements in measures of symptom severity during off but not during on phases, similar to the observations of Goetz et al. (58). Thus most of the findings of Kelly et al. (78) are very much in agreement with those of Goetz et al. $(58,60)$.

The two studies $(58,78)$ appeared to differ significantly in the degree of improvement in on time without dyskinesia (presumably similar to chorea), as determined by diary records. The Kelly et al. (78) study also observed an increase, but to a much smaller degree than that observed by Goetz and co-workers (58) and Penn $e t$ al. (110). The baseline on time without dyskinesia in the Kelly et al. (78) study was, however, much greater than (about double) the baseline on time without chorea from the Goetz et al. (58) study, possibly resulting in a ceiling effect. It is very interesting that there was only one patient in the Kelly et al. (78) study that showed a baseline on time without chorea/dyskinesia similar to that observed by Goetz et al. (58) of $4 \mathrm{~h}$ per day, and this patient showed a large increase, to almost $13 \mathrm{~h}$ per day, 6 months after transplantation. A reasonable hypothesis, therefore, is that adrenal medulla grafts markedly increase on time without chorea/dyskinesia for patients having baseline on times without chorea/dyskinesia in the 3 to $5 \mathrm{~h}$ per day range. If such a change occurs it would certainly be of clinical value, and baseline on time without chorea might prove to be a predictor of clinical response to adrenal medulla grafts.

A recent study by Flores and co-workers (38) also employed the Madrazo technique, and the improvements found in this study were also relatively minor. Only 4 of 
the 22 patients showed long-term improvement, and the remainder showed brief periods of improvement only. In general, the degree of improvement seen was small.

A slightly different approach was employed in a clinical trial by Allen and associates (2). The surgical approach was similar to that employed by Madrazo et al. (90), except that the adrenal medulla tissue was held in place by (i) covering the graft with a piece of gelatin sponge and autologous blood or cryoprecipitate and thrombin (3 patients), or (ii) covering the graft with a Dexon net held in place by cryoprecipitate and thrombin (15 patients). It was concluded that distinct improvements, lasting at least 1 year, were seen in some of the patients. Examination of the data, in fact, reveals that the first 3 patients (graft covered with gelfoam) showed a mean improvement in the Columbia rating scale scores of $7 \%$, compared to a $15 \%$ improvement for the patients receiving the grafts covered by the Dexon net. This degree of improvement is not great. In a few individual patients, however, a very substantial improvement was observed (maximum 67\%). It is also noteworthy that the Columbia rating scale probably detects global changes adequately, but may not be the ideal instrument for detecting small or lateralized changes in motor function.

Patient age and symptom severity were varied in this latter study, and the data tended to suggest that younger patients with less severe symptoms showed the greatest improvements. The possibility of better outcome in younger patients would be consistent with the original study by Madrazo and co-workers $(30,90)$. These variables (age and symptom severity) have not as yet been varied systematically, and this conclusion should be interpreted cautiously. It is interesting, however, that animal data also suggest that adrenal medulla grafts from normal aging donors $(42,45)$, and from young donors in aging hosts (26), are less effective. There is also evidence of decreased catecholamine concentrations in the adrenal medulla of patients with Parkinson's disease (141). Both of these phenomena, progressive damage to the adrenal medulla from the disease process and decreased efficacy of adrenal medulla grafts in aging individuals, could conceivably contribute to a decreased efficacy of this procedure in older patients.

\section{B. Postmortem Studies in Human Patients}

Several human patients that received adrenal medulla grafts for Parkinson's disease have come to autopsy and have been examined carefully $(28,40,71,72$, $73,113)$. Most of these autopsies were from cases that did not show improvement as a result of the transplantation, and in most of these cases it did not appear that adrenal chromaffin cells had survived $(28,40,71)$. Thus no conclusions about the possible mechanisms of func- tional improvement can be drawn from these particular cases. It is also unclear whether the entire graft area was sectioned in some cases. One thoroughly studied case was from a patient who died 4 months after surgery but who did not improve. Evidence for the survival of transplanted chromaffin cells as well as decreases in striatal dopamine receptors was obtained (72). The surviving chromaffin cells were identified by chromogranin A immunoreactivity, but did not show TH immunoreactivity. In the case reported by Peterson and co-workers (113), the graft did not survive but it is unclear whether or not the patient improved (see above, section VI A). A case examined by Jankovic and co-workers (73) showed some improvement prior to death, but surviving chromaffin cells were not found, and no $\mathrm{TH}$ immunoreactivity was found either in the graft or in the surrounding host brain. It is probably more likely that patients with poor outcomes would come to autopsy sooner. Nevertheless, the consistent lack of TH-immunoreactive cells at least indicates that the adrenal medulla grafts in many cases are either not surviving after transplantation in clinical trials or are surviving but failing to express TH (72).

\section{Comments and Summary of Clinical Studies}

In general, intrastriatal adrenal medulla grafts appear to cause only a transient improvement, whereas intraventricular grafts seem to cause a more lasting effect. The degree of clinical improvement has been variable. In the Madrazo et al. (90) study, a very substantial improvement was reported, while in most other studies $(2,5,38,78)$ the improvements have been smaller. The significance of these more modest improvements has been very controversial (e.g., $(57,73,148,163)$ ), particularly in light of the relatively frequent deaths and adverse side effects. The major improvements that have been observed have been significant increases in durations of on times, particularly on times without chorea in patients that have on time without chorea for only a small part of each waking day $(58,60)$. Derivation of TFS scores, which consist of weighted average levels of functioning over the course of the waking day (Table 2), suggests that the changes seen in these latter studies $(58,60)$ constitute a loss of about $50 \%$ of the average baseline functional deficit.

The on and off fluctuations in Parkinson's disease also cause difficulties for the quantification of symptom severity. Goetz and co-workers $(58,60)$ have very effectively dealt with this issue by measuring clinical status during on and off states separately and quantifying the amount of on and off time. Although this appears to be a highly accurate and efficient technique, the nature of the changes that were seen leaves open some question about interpretation. A simple change in on and off du- 
rations per se would be consistent with the observed changes. On the other hand, if symptom severity were simply altered by a small amount at all times, patients might rate themselves as being in an on state more frequently and show modest improvements during off states, but show no change during on states because the slight effect of the graft was overwhelmed by the large therapeutic effect of $\mathrm{L}$-DOPA.

Even within the studies that have seen modest improvements overall there has, however, been a great degree of variability from patient to patient. In several clinical studies $(2,38,73,78)$ the majority of patients have improved only slightly, while a few patients have shown much greater effects. In view of the very variable clinical response, it would seem to be important to develop predictors of outcome. There have been suggestions that outcome may be related to age or symptom severity $(2,30,90)$. The data of Goetz et al. (58) and Kelly et al. (78) tend to suggest that patients with short baseline on times without chorea may show the largest improvements. Another possible predictor would be the condition of the adrenal medulla prior to transplantation, as measured by serum catecholamines (153).

The two methods of adrenal medulla transplantation that have been used clinically are stereotaxically guided intraparenchymal transplantation and visually guided transplantation into cavities in the wall of the lateral ventricle. These two techniques correspond closely to intraparenchymal and intraventricular transplantation, respectively, with one possibly important difference. As used in animals, intraventricular transplantation produces relatively little damage to the host brain parenchyma with only a small injury to the ependyma and brain parenchyma. The human transplantation technique involves the creation of a cavity on the wall of the ventricle. Injury to the brain parenchyma might contribute to the functional effects of adrenal medulla grafts, either by producing or enhancing the trophic effects of these grafts $(15,19,36)$ or by enhancing dopamine-related effects. Thus the human intraventricular transplantation method might at least conceptually be the optimal methodology. That is, contact of the grafts with CSF might allow for good cell survival at least in some cases, while the creation of the cavity might enhance any trophic effects of the grafts. This remains conjectural, however, and the ventricular cavity transplantation method has still only partially (6) been tested using adrenal medulla grafts in animals.

\section{GENERAL CONCLUSIONS AND COMMENTS}

From the above discussion, it is apparent that there are many gaps in the experimental literature on adrenal medulla grafts in rodent and primate models, as well as in human patients. It is apparent that numerous stud- ies, including some of our own, have deficiencies due to the absence of crucial control groups, the necessity of which was not foreseen, usually because the experiments in question yielded results on topics that were not anticipated. Nevertheless, there are certain areas in which recommendations can be made.

First, in studies using rodent models, it is clear that one important issue is the determination of methods that result in consistent, predictable graft survival. Some factors that favor graft survival are known, such as emplacement of grafts in the ventricle or the addition of NGF infusions. Data on numbers of cells surviving in each circumstance with and without NGF are lacking. It is also apparent that adrenal medulla grafts do not always survive, even in the lateral ventricle. It is important to determine what circumstances result in graft survival in the ventricle and to experimentally manipulate these factors as an independent variable in controlled experiments, using objective measures of graft survival (e.g., cell counts). Once predictable survival of adrenal medulla grafts can be consistently obtained, whether there are specific effects of chromaffin cells (i.e., effects based on secretion of catecholamines from the grafts) can be determined.

On the other hand, putative trophic effects of adrenal medulla grafts may also occur. What is needed in this context is again, controlled experiments that employ objective, quantifiable measures. Immunohistochemistry adapts to quantification only with some difficulty, because of staining variability between animals. At this point, it appears to be important to employ several types of controls including inactive tissue grafts and nongrafted controls to assess whether these trophic effects are specific to adrenal medulla. Assessment techniques in addition to $\mathrm{TH}$ immunoreactivity, such as measurements of TH mRNA, TH catalytic activity, or dopamine production are needed to rule out possible artifacts resulting from reliance on a single method of assessment.

There are indications that adrenal medulla grafts may produce two different effects on host brain. When the grafts survive, they may produce functional effects through release of dopamine and possibly other substances. As might be expected, most evidence suggests that grafts in the ventricle produce functional effects only when they survive. When substantial numbers of chromaffin cells survive in intraparenchymal grafts, it is possible that these grafts also produce functional effects through a similar mechanism. If the chromaffin cells do not survive, they of course do not produce dopamine or other chemical substances. Under this circumstance, functional effects must be attributed to (i) the host brain reaction to injury, (ii) the release of chemical substances with trophic effects greatly outlasting their 
production, or (iii) the production of substances by surviving non-chromaffin cells.

The primary purpose of transplantation experiments in primate models is to test procedures with potential clinical application prior to use in human subjects. It is apparent that many of the things now being tested in human patients could readily be accomplished in primates. The use of primates would also permit histology to be done systematically. It is very unfortunate that increasing restrictions on animal research and the high cost of studies in primates have, in some ways, made it easier to conduct experiments on human subjects than in primate models. Thus, there has not yet been a complete report of a controlled trial of the Madrazo et al. $(90)$ procedure in primates. There are many obvious and fundamental issues that could easily be answered in primates, rather than subjecting human patients to procedures that may not be optimally effective. To take an obvious example, what is the maximum time from removal to implantation of the adrenal medulla that will result in good tissue survival? The opposite side of this issue is that transplantation of adrenal medulla for Parkinson's disease could easily be dismissed as not effective, because some basic procedural problem that could have been worked out in primate models has been overlooked.

Even for clinical trials themselves, there are some fundamental procedural issues that should be addressed. First, it is unfortunate to conduct these trials without obtaining quantitative objective measures of motor function. Most of the clinical trials have employed, at best, rating scales. In some cases only more informal assessments have been used. Measurement reliability has been assessed very infrequently. It is-or should be-fortuitous that Parkinson's disease involves motor deficits that can be so readily quantified. Measures such as those employed by Lindvall et al. (87) and by Freed et al. (41) can provide very precise measurements of the outcome of transplantation procedures and are very easy to implement. If such methods are standardized, it will be possible to determine the amount of improvement in each patient and thereby determine what factors are associated with greater or less clinical improvement. Rating scales, although essential, can provide quantitative information to only a limited degree. It is also time to consider controlled trials involving comparisons of patients receiving adrenal medulla grafts to controls, or at least to nontreated groups or groups receiving other treatments, as it remains unclear whether any of the improvements are due to lesioning or other nonspecific surgical effects. The long-term changes seen after adrenal medulla grafts should also be compared to the expected progression of the disease, rather than to baseline scores only.

Thus, there are indications that autologous transplantation of adrenal medulla to the wall of the lateral ventricle can produce measurable clinical effects in severe Parkinson's disease. That any measurable effects are observed at all is, in fact, surprising: Very large effects should not be expected, considering the modest effects of adrenal medulla grafts even in rats. The degree of improvement seen in most clinical studies is small, with a possibly greater improvement occurring in a minority of patients. There are indications that nonchorea on time may be substantially improved, and some patients may improve markedly. Certainly, a doubling of non-chorea on time in severely ill patients could be clinically significant, and use of the total function scale suggests that substantial improvement may occur in some patients. Very little attention has been paid to the reliability of outcome measures. The incidence of death and serious morbidity has been substantial and adverse side effects occur. At least over the short term, side effects seem to be very frequent $(60,106)$. Whether the magnitude of the positive effects is sufficient to justify the associated risks has not been resolved, and it is not clear how consistently these effects can be produced.

There is a possibility that adrenal medulla transplantation procedures are differentially effective in different trials, depending on minor variations in technique. Factors such as length of time between adrenal medulla removal and implantation, inclusion of adrenal cortex in the grafts, variations in implantation technique and site, length of illness or age, severity of illness and baseline on time durations, or postoperative administration of L-DOPA may significantly influence outcome. It is particularly important that records of these variables be maintained through the American Association of Neurological Surgeons and the United Parkinson Foundation registries. Nevertheless, much of this information could be obtained more reliably through animal experiments. Eventually these data will have to be gathered in animals if adrenal medulla transplantation is ever to be optimized for human application. Further development of techniques for intraparenchymal adrenal medulla transplantation, hopefully in rodent and primate experiments (eq. (31)), will also be important to allow for transplantation into specific sites. The greater depletion of dopamine in the putamen, as compared to the caudate, in Parkinson's disease patients (81) argues for the possibility of transplantation into the putamen.

It is unclear how these grafts produce behavioral effects in human subjects, and it is in fact possible that some of the effects are due to mechanisms not operative in the animal models that have so far been used (e.g., alterations of entry of L-DOPA into the brain). At the present time the data, either for animals or human subjects, are not sufficient to warrant widespread application of adrenal medulla transplantation as a clinical procedure. Until further data are collected, adrenal medulla transplantation in humans should be performed 
only in the course of carefully planned experimental trials.

\section{ACKNOWLEDGMENTS}

This paper is dedicated to the memory of Cynthia R. Rodgers, who made innumerable contributions to our studies of adrenal medulla grafts prior to her tragic death in 1989 . We also thank the support staff of the NIMH Neuroscience Center for invaluable assistance. This work was supported in part by a grant to J.B.B. (NS22157) and by Research Career Development Award to J.B.B. (NS01056). Travel funds for J.B.B. were provided by the American Parkinson's Disease Association.

\section{REFERENCES}

1. Ahlskog, J. E., G. M. TyCe, P. J. Kelly, J. A. van Heerden, S. L. STODDARD, AND S. W. CARMICHAEL. 1989. Cerebrospinal fluid indices of blood-brain barrier permeability following adrenal-brain transplantation in patients with Parkinson's disease. Exp. Neurol. 105: 152-161.

2. Allen, G. S., R. S. Burns, N. B. Tulipan, and R. A. Parker. 1989. Adrenal medullary transplant to the caudate nucleus in Parkinson's disease. Initial results in 18 patients. Arch. Neurol. 46: $487-491$.

3. Assouline, J. G., P. Bosch, R. LIM, I. S. KIM, R. JENSEN, AND N. J. PANTAZIs. 1987. Rat astrocytes and Schwann cells in culture synthesize nerve growth factor-like neurite-promoting factors. Dev. Brain Res. 31: 103-118.

4. Backitinn, F.-O., P.-O. Granberg, B. Hamberger, E. KNutSon, A. Martensson, G. Sedvall, A. Seiger, and L. Olson. 1985. Transplantation of adrenal medullary tissue to striatum in parkinsonism. First clinical trials. $J$. Neurosurg. 62: 169173.

5. Bakay, R. A. E. 1989. Preliminary report on adrenal medullary grafting from the American Association of Neurological Surgeons GRAFT project. Restorative Neurol. Neurosci. 1: 160.

6. Bakay, R. A. E., C. J. Herring, R. L. Watts, P. M. Iuvone, AND L. D. BYRD. 1990. Adrenal medullary grafting in the treatment of hemiparkinsonian monkeys. Restorative Neurol. Neurosci. 1: 158.

7. Bankiewicz, K. S., R. J. PlunketT, D. Jacobowitz, L. Porrino, U. diPorzio, W. T. London, I. J. Kopin, AND E. H. OLDFIELD. 1990. The effect of fetal mesencephalon implants on primate MPTP-induced parkinsonism. J. Neurosurg. 72: 231244.

8. Bankiewicz, K. S., R. J. Plunkett, I. J. Kopin, D. M. JacobowITZ, W. T. London, and E. H. OldField. 1988. Transient behavioral recovery in hemiparkinsonian primates after adrenal medullary autografts. Prog. Brain Res. 78: 507-511.

9. BARKer, R. 1989. Adrenal grafting for Parkinson's disease-A role for substance P. Int. J. Neurosci. 46: 47-51.

10. Becker, J. B., E. J. Curran, AND W. J. Freed. 1990. Adrenal medulla graft induced recovery of function in an animal model of Parkinson's disease: Possible mechanisms of action. Canad. J. Psychol. 44: 293-310.

11. Becker, J. B., E. J. Curran, W. J. Freed, and M. Poltorak. 1990. Mechanisms of action of adrenal medulla grafts: The possible role of peripheral and central dopamine systems. Prog. Brain Res. 82.

12. BeCker, J. B., AND W. J. FreED. 1988. Adrenal medulla grafts enhance functional activity of the striatal dopamine system following substantia nigra lesions. Brain Res. 462: 401-406.
13. BECKER, J. B., AND W. J. FREED. 1988. Neurochemical correlates of behavioral changes following intraventricular adrenal medulla grafts: Intraventricular microdialysis in freely moving rats. Prog. Brain Res. 78: 527-533.

14. Becker, J. B., T. E. Robinson, P. Barton, A. Sintov, R. SIDEN, AND R. J. LEVY. 1990. Sustained behavioral recovery from unilateral nigrostriatal damage produced by the controlled release of dopamine from a silicone polymer pellet placed into the denervated striatum. Brain Res. 508: 60-64.

15. Bing, G., M. F. D. NotTer, J. T. Hansen, and D. M. Gash. 1988. Comparison of adrenal medullary, carotid body, and PC12 cell grafts in 6-OHDA lesioned rats. Brain Res. Bull. 20: 399-406.

16. BJElke, B., K. FuXE, AND L. F. AgNati. 1988. Survival of adenohypophyseal homologous transplants in the rat striatum associated with prolactin-like immunoreactivity in the surrounding neuropil of the striatum. Neurosci. Lett. 93: 139-145.

17. BJorklund, A., S. B. Dunnett, U. Stenevi, M. E. Lewis, AND S. D. IVERSEN. 1980. Reinnervation of the denervated striatum by substantia nigra transplants: Functional consequences as revealed by pharmacological and sensorimotor testing. Brain Res. 199: 307-333.

18. Blotther, D., R. WestermanN, C. Grothe, P. Bohlen, AND K. UNSICKER. 1989. Basic fibroblast growth factor in the adrenal gland: possible trophic role for preganglionic neurons in vivo. Fur. J. Neurosci. 1: 471-478.

19. Bohn, M. C., F. Marclano, L. Cupit, and D. M. Gash. 1987. Adrenal medullary grafts promote recovery of striatal dopaminergic fibers in MPTP treated mice. Science 237: 913-916.

20. BRown, V. J., AND S. B. DUNNETT. 1989. Comparison of adrenal and foetal nigral grafts on drug-induced rotation in rats with 6-OHDA lesions. Exp. Brain Res. 78: 214-218.

21. Burns, R. S., G. S. Allen, AND N. B. TulipaN. 1988. Adrenal medullary transplants to caudate nucleus in Parkinson's disease. Neurology 38(Suppl. 1): 143.

22. Carvey, P. M., J. S. KroIN, AND T. J. Zhang. 1988. Biochemical and immunochemical characterization of ventricular CSF from Parkinson's disease (PD) patients with adrenal medullary transplants. Neurology 38(Suppl. 1): 144.

23. Chang, G. D., and V. D. Ramirez. 1988. A potent dopaminereleasing factor is present in high concentrations in the rat adrenal gland. Brain Res. 463: 385-389.

24. Cotzias, G. C., P. S. Papavasiliou, and R. Gellent. 1969. Modification of parkinsonism: chronic treatment with $\mathrm{L}$ DOPA. N. Engl. J. Med. 280: 337-345.

25. Dal Toso, R., O. Giorgi, C. Soranzo, G. Kirschner, G. Ferrari, M. Favaron, D. Benvegno, D. Presti, S. Vicini, G. Toffano, G. F. Azzone, AND A. LEON. 1988. Development and survival of neurons in dissociated fetal mesencephalic serumfree cell cultures. I. Effects of cell density and of an adult mammalian striatal-derived neuronotrophic factor (SDNF). $J$. Neurosci. 8: $733-745$.

26. Date, I., S. Y. Felten, J. A. Olschowka, and D. L. Felten. 1990. Limited recovery of striatal dopaminergic fibers by adrenal medullary grafts in MPTP-treated aging mice. Exp. Neurol. 107: $197-207$.

27. Decombe, R., J. P. Rivot, D. Aunis, N. Abrous, M. PesCHANSKI, AND J. P. HERMAN. 1990. Importance of catecholamine release for the functional action of intrastriatal implants of adrenal medullary cells: Pharmacological analysis and in vivo electrochemistry. Exp. Neurol. 107: 143-153.

28. Dohan, F. C., J. T. Robertson, C. Feler, J. Schweitzer, C. Hall, AND J. H. Robertson. 1988. Autopsy findings in a Par- 
kinson's disease patient treated with adrenal medullary to caudate nucleus transplant. Soc. Neurosci. Abstr. 14: 8 .

29. Doupe, A. J., S. C. LANdis, AND P. H. PatTerson. 1985. Environmental influences in the development of neural crest derivatives: Glucocorticoids, growth factors, and chromaffin cell plasticity. J. Neurosci. 5: 2119-2142.

30. Drucker-Colin, R., I. Madrazo, F. Ostrosky-Solis, M. SNKuRovich, R. Franco, AND C. Torres. 1988. Adrenal medullary tissue transplants in the caudate nucleus of Parkinson's patients. Prog. Brain Res. 78: 567-574.

31. DuBACH, M., aND D. C. German. 1989. Solid adrenal grafts in long-tailed macaques: Stereotaxic implantation and biochemical stimulation. Soc. Neurosci. Abstr. 15: 1356.

32. Dunnett, S. B., A. Bjorklund, R. H. Schmidt, U. Stenevi, AND S. D. IVERSEN. 1983. Intracerebral grafting of neuronal cell suspensions. IV. Behavioral recovery in rats with unilateral 6 OHDA lesions following implantation of nigral cell suspensions in different forebrain sites. Acta Physiol. Scand. (Suppl.) 522: 29-37.

33. Dunnett, S. B., T. D. Hernandez, A. Summerfield, G. H. JONES, AND G. ARBUTHNOTT. 1988. Graft-derived recovery from 6-OHDA lesions: Specificity of ventral mesencephalic graft tissues. Exp. Brain Res. 71 : 411-424.

34. Dymecki, J., M. Poltorak, D. Markiewicz, M. HauptmanN, W. DzIEDZIAK, AND W. KosTowSKI. 1986. Effects of intracerebral transplantations of the adrenal medulla in rats with experimental Parkinson's disease. Neuropatol. Pol. 24: 29-42.

35. Edelman, G. M. 1983. Cell adhesion molecules. Science 219: 450-457.

36. Fiandaca, M. S., J. H. Kordower, J. T. Hansen, S.-S. Jiao, AND D. M. GASH. 1988. Adrenal medullary autografts into the basal ganglia of cebus monkeys: Injury-induced regeneration. Exp. Neurol. 102: 76-91.

37. Fitzgerald, L. R., S. D. Glick, and A. S. Schneider. 1989. Fffect of striatal implantation of bovine adrenal chromaffin cells on turning behavior in a rat model of Parkinson's disease. Brain Res. 481: 373-377.

38. FLoREs, E. G. 1990. Is autologous transplant of adrenal medulla into the striatum an effective therapy for Parkinson's disease? Restorative Neurol. Neurosci. 1: 182.

39. Fontana, A., F. Kristensen, R. Dubs, D. Gemsa, and E. Weber. 1982. Production of prostaglandin $\mathrm{E}$ and an interleukin-1 like factor by cultured astrocytes and $\mathrm{C} 6$ cells. $J$. Immunol. 129: 2413-2419.

40. Forno, L. S., AND J. W. LANGSTON. 1989. Adrenal medullary transplant to the brain for Parkinson's disease. Neuropathology of an unsuccessful case. J. Neuropathol. Exp. Neurol. 48: 339.

41. Freed, C. R., R. E. Breeze, N. L. Rosenberg, S. A. SchnecK, T. H. Wells, J. N. Barrett, S. T. Grafton, S. C. Huang, D. EidelberG, AND D. A. ROTTENBERG. 1990. Transplantation of human fetal dopamine cells for Parkinson's disease: Results at 1 year. Arch. Neurol. 47: 505-512.

42. FREED, W. J. 1983. Functional brain tissue transplantation: Reversal of lesion-induced rotation by intraventricular substantia nigra and adrenal medulla grafts, with a note on intracranial retinal grafts. Biol. Psychiaty 18: 1205-1267.

43. FreED, W. J. 1985. Transplantation of tissues to the cerebral ventricles: Methodological details and rate of graft survival. In Neural Grafting in the Mammalian CNS (A. Bjorklund and U. Stenevi, Eds.), pp. 31-40. Elsevier, Amsterdam.

44. Freed, W. J., AND H. E. CANNON-SPOOR. 1988. Cortical lesions increase reinnervation of the dorsal striatum by substantia nigra grafts. Brain Res. 446: 133-143.

45. Freed, W. J., H. E. Cannon-Spoor, and E. Krauthamer. 1986. Intrastriatal adrenal medulla grafts in rats: Long-term survival and behavioral effects. J. Neurosurg. 65: 664-670.

46. Freed, W. J., B. J. Hoffer, L. Olson, AND R. J. WyatT. 1984. Transplantation of catecholamine-containing tissues to restore the functional capacity of the damaged nigrostriatal system. In Neural Transplants (J. R. Sladek and D. M. Gash, Eds.), pp. 373-406. Plenum, New York.

47. Freed, W. J., F. Karoum, H. E. Spoor, L. Olson, J. MoriHISA, AND R. J. WYATT. 1983. Catecholamine content of intracerebral adrenal medulla grafts. Brain Res. 269: 184-189.

48. Freed, W. J., G. N. Ko, D. L. Niehoff, M. J. Kuhar, B. J. Hoffer, L. Olson, H. E. CanNon-Spoor, J. M. Morihisa, AND R. J. WYATT. 1983. Normalization of spiroperidol binding in the denervated rat striatum by homologous grafts of substantia nigra. Science 222: 937-939.

49. Freed, W. J., J. Morihisa, E. Spoor, B. Hoffer, L. Olson, A. SEIGER, AND R. J. WYATT. 1981. Transplanted adrenal chromaffin cells in rat brain reduce lesion-induced rotational behavior. Nature (London) 292: 351-352.

50. Freed, W. J., L. Olson, G. N. Ko, J. M. Morihisa, D. NiehoFf, I. STromberg, M. KuHAR, B. J. HoFFER, AND R. J. WYATT. 1985. Intraventricular substantia nigra and adrenal medulla grafts: Mechanisms of action and $\left[{ }^{3} \mathrm{H}\right]$ spiroperidol autoradiography. In Neural Grafting in the Mammalian CNS (A. Bjorklund, and U. Stenevi, Eds.), pp. 471-489. Elsevier, Amsterdam.

51. Freed, W. J., U. Patel-Vaidya, and H. M. Geller. 1986. Properties of PCl2 pheochromocytoma cells transplanted to the adult rat brain. Exp. Brain Res. 63: 557-566.

52. Freed, W. J., M. J. Perlow, F. Karoum, A. Seiger, L. Olson, B. J. HoFFER, AND R. WYATT. 1980. Restoration of dopaminergic function by grafting of fetal rat substantia nigra to the caudate nucleus: Long term behavioral, biochemical, and histochemical studies. Ann. Neurol. 8: 510-519.

53. Freund, T. F., I. P. Bolam, A. Bjorklund, U. Stenevi, S. B. DuNNETT, J. F. Powell, AND A. D. SMITH. 1985. Efferent synaptic connections of grafted dopaminergic neurons reinnervating the host neostriatum: A tyrosine hydroxylase imsunocytochemical study. J. Neurosci. 5: 603-616.

54. Gash, D. M., J. H. Kordower, M. S. Fiandaca, S. H. OKaWara, S. S. JiaO, M. F. D. NotTer, AND J. T. Hansen. 1988. Adrenal medullary autografts in nonhuman primates: Regeneration and sprouting of host dopaminergic systems. Soc. Neurosci. Abstr. 14: 735.

55. Gash, D. M., M. F. D. NotTer, J. T. Hansen, G. Bing, and S.-H. OKaWARA. 1988. Human organ donor adrenals: fine structure, plasticity, and viability. Transplantation in the Mammalian CNS. Prog. Brain Res. 78: 559-565.

56. Giulian, D., D. G. Young, J. Woodward, D. C. Brown, and L. B. LACHMAN. 1988. Interleukin-1 is an astroglial growth factor in the developing brain. $J$. Neurosci. 8: 709-714.

57. Goetz, C. G., C. W. Olanow, and W. C. Koller. 1989. Correspondence. $N$. Engl. J. Med. 321: 322-327.

58. Goetz, C. G., C. W. Olanow, W. C. Koller, R. D. Penn, D. Cahill, R. Morantz, G. Stebrins, C. M. TANner, H. L. KlaAwans, K. M. Shannon, C. L. Comella, T. WitT, C. CoX, M. WAXMAN, AND L. GAUGER. 1989. Multicenter study of autologous adrenal medullary transplantation of the corpus striatum in patients with advanced Parkinson's disease. N. Engl. J. Med. 320: $337-341$. 
59. Goetz, C. G., G. T. Stebins, H. L. Klawans, W. C. Koller, R. Grossman, R. Bakay, and R. D. Penn. 1989. United Parkinson Foundation Neural Transplantation Registry: 12 Month Data. Restorative Neurol. Neurosci. 1: 160.

60. Goetz, C. G., C. M. Tanner, R. L. Penn, G. T. Stebins, D. W. Gilley, K. M. Shannon, H. L. Klawans, C. L. CoMELLA, R. S. WILSON, AND T. WITT. 1990. Adrenal medullary transplant to the striatum of patients with advanced Parkinson's disease: 1-Year motor and psychomotor data. Neurology 40: $273-276$.

61. GROTHE, C., H.-D. HofmAN, A. A. J. VERHOFSTAD, AND K. UNSICKER. 1985. Nerve growth factor and dexamethasone specify the catecholaminergic phenotype of cultured rat chromaffin cells: dependence on developmental stage. Dev. Brain Res. 21: 125-132.

62. Hallman, H., J. Lange, L. Olson, I. Stromberg, and G. JONSSON. 1985. Neurochemical and histochemical characterization of neurotoxic effects of 1-methyl-4-phenyl-1,2,3,6-tetrahydropyridine on brain catecholamine neurons in the mouse. $J$. Neurochem. 44: 117-127.

63. Hansen, J. T., G. Bing, M. F. D. NotTer, and D. M. Gash. 1988. Paraneuronal grafts in unilateral 6-hydroxydopamine-lesioned rats: Morphological aspects of adrenal chromaffin and carotid body glomus cell implants. Prog. Brain Res. 78: 507511.

64. Hansen, J. T., M. S. Fiandaca, J. H. Kordower, M. F. D. NOTTER, AND D. M. GASH. 1989. Striatal adrenal medulla/sural nerve co-grafts in hemi-parkinsonian monkeys. Restorative Neurol. Neurosci. 1: 109-110.

65. Hansen, J. T., J. H. Kordower, M. S. Fiandaca, S.-S. Jiao, M. F. D. NotTeR, AND D. M. GASH. 1988. Adrenal medullary autografts into the basal ganglia of cebus monkeys: Graft viability and fine structure. Exp. Neurol. 102: 65-75.

66. Hansen, J. T., M. F. D. NotTer, S.-H. Okawara, and D. M. GASH. 1988. Organization, fine structure, and viability of the human adrenal medulla: Considerations for neural transplantation. Ann. Neurol. 24: 599-609.

67. Hargraves, R., AND W. J. Freed. 1987. Chronic intrastriatal dopamine infusions in rats with unilateral lesions of the substantia nigra. Life Sci. 40: 959-966.

68. Hefti, F., E. MElamed, AND R. J. WuRtman. 1981. The site of dopamine formation in rat striatum after L-dopa administration. J. Pharmacol. Exp. Ther. 217 : 189-197.

69. HeLler, A., AND L. WON. 1985. Selective association of dopaminergic (DA) axons with their striatal targets in vitro. Soc. Neurosci. Abstr. 1 1: G6.

70. Herrera-Marschitz, M., I. Stromberg, D. Olsson, U. UNGERSTEDT, AND L. OLSON. 1984. Adrenal medullary implants in the dopamine-denervated rat striatum. II. Acute behavior as a function of graft amount and location and its modulation by neuroleptics. Brain Res. 297: 53-61.

71. HiRsch, E. C., C. Duyckaerts, F. Javoy-AGin, J.-J. Hauw, AND Y. AGID. 1990. Does adrenal graft enhance recovery of dopaminergic neurons in Parkinson's disease? Ann. Neurol., 27: 676-682.

72. Hurtig, H., J. Joyce, J. R. Sladek, and J. Q. Trojanowski. 1989. Postmortem analysis of adrenal-medulla-to-caudate autograft in a patient with Parkinson's disease. Ann. Neurol. 25: 607-614.

73. Jankovic, J., R. Grossman, C. Goodman, F. Pirozzolo, L. Schneider, Z. Zhu, P. Scardino, A. J. Garber, S. G. JHINGRAN, AND S. MARTIN. 1989. Clinical, biochemical, and neuropathologic findings following transplantation of adrenal me- dulla to the caudate nucleus for treatment of Parkinson's disease. Neurology 39: 1227-1234.

74. JiaO, S.-S., Y.-J. DING, W.-C. ZhaNG, J.-K. CAO, G.-F. ZHANG, Z.-M. Zhang, M.-C. Ding, Z. Zhang, AND J.-M. MENG. 1989. Adrenal medullary autografts in patients with Parkinson's disease. N. Engl. J. Med. 321 : 324-325.

75. Jlao, S., W. Zhang, J. Cao, Z. Zhang, H. Wang, M. Ding, Z ZhaNG, J. Sun, Y. SuN, AND M. SHI. 1988. Study of adrenal medullary tissue transplantation to striatum in parkinsonism. Prog. Brain Res. 78: 575-580.

76. JouSSELIN-HoSAJA, M. 1988. Uitrastructural evidence for the development of adrenal medullary grafts in the brain. Exp. Brain Res. 73: 637-647.

77. Kamo, H., S. U. KIM, P. L. McGeER, H. TAGo, AND D. H. ShIN. 1987. Transplantation of cultured human adrenal chromaffin cells into 6-hydroxydopamine-lesioned rat brain. Synapse 1: 324-328.

78. Kelly, P. J., J. E. Ahlskog, J. A. van HeERden, S. W. CarmiCHAEL, S. L. StoddaRd, AND G. N. BELl. 1989. Adrenal medullary autograft transplantation into the striatum of patients with Parkinson's disease. Mayo Clin. Proc. 64: 282-290.

79. KEMMLER, J. E., AND J. SAGEN. 1989. Increased catecholamine levels in spinal cord superfusates of rats with adrenal medulla implants. Soc. Neurosci. Abstr. 15: 1243.

80. Kirshner, N. 1975. Biosynthesis of the catecholamines. In The Adrenal Gland, Handbook of Endocrinology (H. Blaschko, G. Sayers, and A. D. Smith, Eds.), Vol 6, pp. 341-355. Amer. Physiol. Soc., Washington, DC.

81. KISH, S. J., K. ShanNaK, AND O. HornykiEWICZ. 1988. Uneven pattern of dopamine loss in the striatum of patients with idiopathic Parkinson's disease. N. Engl. J. Med. 318: 876-880.

82. Koller, W. C., R. Morantz, B. Vetere-Overfield, and M. WAXMAN. 1989. Autologous adrenal medullary transplant in progressive supranuclear palsy. Neurology 39: 1066-1068.

83. Korsching, S., G. Auburger, R. Heumann, J. Scott, and H. THOENEN. 1985. Levels of nerve growth factor and its mRNA in the central nervous system of the rat correlate with cholinergic innervation. EMBO J. 4: 1389-1393.

84. LeVi-Montalcini, R. 1975. The nerve growth factor: Its role in growth, differentiation and function of the sympathetic adrenergic neuron. Prog. Brain Res. 45: 235-258.

85. Levi-Montalcini, R. 1987. The nerve growth factor: Thirtyfive years later. $E M B O J$ J 6: 1145-1154.

86. Lindholm, D., R. HeumanN, M. Meyer, and H. Thoenen. 1987. Interleukin-1 regulates synthesis of nerve growth factor in non-neuronal cells of rat sciatic nerve. Nature (London) 330: 658-659.

87. Lindvall, O., E.-O. Backlund, L. Farde, G. Sedvall, R. Freedman, B. Hoffer, A. Nobin, A. Seiger, ANd L. Olson. 1987. Transplantation in Parkinson's disease: Two cases of adrenal medullary grafts to the putamen. Ann. Neurol. 22: 457468.

88. Lindvall, O., P. Brundin, H. Widner, S. Rehncrona, B. Gustavi, R. Frackowiak, K. L. Leenders, G. Sawle, J. C. Rothwell, C. D. Marsden, AND A. BJorkLund. 1990. Grafts of fetal dopamine neurons survive and improve motor function in Parkinson's disease. Science 247: 574-577.

89. LJUNGBERG, T., AND U. UNGERSTEDT. 1976. Reinstatement of eating by dopamine agonists in aphagic dopamine-denervated rats. Physiol. Behav. 16: 277-283.

90. Madrazo, I., R. Drucker-Colin, V. Diaz, J. MartinezMARTA, C. TORRES, AND J. J. BECERRIL. 1987. Open microsur- 
gical autograft of adrenal medulla to the right caudate nucleus in Parkinson's disease: A report of two cases. N. Engl. J. Med. 316: 831-834.

91. Madrazo, I., R. Drucker-Colin, V. Leon, and C. Torres. 1987. Adrenal medulla transplanted to caudate nucleus for treatment of Parkinson's disease: Report of 10 cases. Surg. Forum 38: 510-511.

92. Madrazo, I., V. Leon, C. Torres, A. M. Del Carmen, G. Varella, F. Alvarez, A. Fraga, R. Drucker-Colin, F. OsTROSKY, M. SkURovich, AND R. Franco. 1987. Transplantation of fetal substantia nigra and adrenal medulla to the caudate in two patients with Parkinson's disease. N. Engl. J. Med. 318: 51.

93. Mahalik, T. J., T. E. Finger, I. Stromberg, and L. Olson. 1985. Substantia nigra transplants into denervated striatum of the rat: Ultrastructure of graft and host connections. J. Comp. Neurol. 240: 60-70.

94. Marshall, J. F., AND T. GotTHELF. 1979. Sensory inattention in rats with 6-hydroxydopamine-induced degeneration of ascending dopaminergic neurons: Apomorphine-induced reversal of deficits. Exp. Neurol. 65: 398-411.

95. McRae-Degueurce, A., H. L. Klawans, R. D. Penn, A. Dahlstrom, C. M. Tanner, C. G. Goetz, and P. M. Carvey. 1988. An antibody in the CSF of Parkinson's disease patients disappears following adrenal medulla transplantation. Neurosci. Lett. 94: 192-197.

96. Morihisa, J. M., R. K. Nakamura, W. J. Freed, M. Mishkin, AND R. J. WYATT. 1984. Adrenal medulla grafts survive and exhibit catecholamine specific fluorescence in the primate brain. Exp. Neurol. 84: 643-653.

97. Nappi, G., F. Petraglia, E. Martignoni, F. Facchinetti, G. BONO, AND A. R. GENAZZANI. 1985. $\beta$-Endorphin cerebrospinal fluid decrease in untreated parkinsonian patients. Neurology 35: 1371-1374.

98. Nieto-Sampedro, M., E. R. Lewis, C. W. Cotman, M. MANTHORPE, S. D. SkAPER, G. BARBIN, F. M. LONGO, AND S. VARON. 1982. Brain injury causes a time-dependent increase in neuronotrophic activity at the lesion site. Science 217: 860861.

99. Nieto-Sampedro, M., S. R. Whittemore, D. L. Needels, J. LARSON, AND C. W. CoTMAN. 1984. The survival of brain transplants is enhanced by extracts from injured brain. Proc. Natl. Acad. Sci. USA 81: 6250-6254.

100. Nishino, H., T. Ono, R. Shibata, S. Kawamata, H. WataNabe, S. Shiosaka, M. Tohyema, and Z. Karadi. 1988. Adrenal medullary cells transmute into dopaminergic neurons in dopamine-depleted rat caudate and ameliorate motor disturbances. Brain Res. 445: 325-337.

101. Nishino, H., T. Ono, J. Takahashi, M. Kimura, S. Shiosaka, AND M. TOHYAMA. 1986. Transplants in the peri- and intraventricular region grow better than those in the central parenchyma of the caudate. Neurosei. Lett. 64: 184-190.

102. Obeso, J. A., M. R. Luquin, AND J. M. MaRTINez-Lage. 1986. Lisuride infusion pump: A device for the treatment of motor fluctuations in Parkinson's disease. Lancet 1: 467-470.

103. Olson, L. 1970. Fluorescence histochemical evidence for axonal growth and secretion from transplanted adrenal medullary tissue. Histochemie 22: 1-7.

104. Olson, L., A. Seiger, R. Freedman, and B. Hoffer. 1980. Chromaffin cells can innervate brain tissue: Evidence from intraocular double grafts. Exp. Neurol. 70: 414-426.

105. Olson, L., I. Stromberg, M. Herrera-Marschitz, U. UNGERSTEDT, AND T. EBENDAL. 1985. Adrenal medullary tissue grafted to the dopamine-denervated rat striatum: histochemical and functional effects of additions of nerve growth factor. In Neuronal Grafting in the Mammalian CNS (A. Bjorklund and U. Stenevi, Eds.), pp. 505-518. Elsevier, Amsterdam.

106. Ostrosky-Solis, F., L. Quintanar, I. Madrazo, R. DRUCKER-Colin, R. Franco-BourLAND, AND V. LEON-MEZA. 1988. Neuropsychological effects of brain autograft of adrenal medullary tissue for the treatment of Parkinson's disease. Neurology 38: 1442-1450.

107. OTTO, D., AND K. UNSICKER. 1990. Basic FGF reverses chemical and morphological deficits in the nigrostriatal system of MPTP treated mice. J. Neurosci., 10: 1912-1921.

108. PAPPAS, G. D., AND J. SAGEN. 1988. Fine structural correlates of vascular permeability of chromaffin cell transplants in CNS pain modulatory regions. Exp. Neurol. 102: 280-289.

109. Patel-Vaidya, U., M. R. Wells, and W. J. Freed. 1985. Survival of dissociated adrenal chromaffin cells of rat and monkey transplanted into rat brain. Cell Tissue Res. 240: 281-285.

110. Penn, R. D., C. G. Goetz, C. M. Tanner, H. L. Klawans, K. M. Shannon, C. L. Comella, and T. R. Witt. 1988. The adrenal medullary transplant operation for Parkinson's disease: Clinical observations in five patients. Neurosurgery 22: 999-1004.

111. Perlow, M., W. J. Freed, B. Hoffer, A. Seiger, L. Olson, AND R. J. WYATT. 1979. Brain grafts reduce motor abnormalities produced by destruction of nigrostriatal dopamine system. Science 204: 643-647.

112. Perlow, M. J., K. Kumakura, And A. GuidotTi. 1980. Prolonged survival of bovine adrenal chromaffin cells in rat cerebral ventricles. Proc. Natl. Acad. Sci. USA 77: 5278-5281.

113. Peterson, D. I., M. L. Price, and C. S. Small. 1989. Autopsy findings in a patient who had an adrenal-to brain transplant for Parkinson's disease. Neurology 39: 235-238.

114. Pezzoli, G., S. Fahn, A. Dwork, D. D. Truong, J. G. De YeBENES, V. JACKSON-LEWIS, J. HERBERT, AND J. L. CADET. 1988. Non-chromaffin tissue plus nerve growth factor reduces experimental parkinsonism in aged rats. Brain Res. 459: 398-403.

115. Poltorak, M., W. J. Freed, L. A. Sterngerger, and N. H. STERNBERGER. 1988. A comparison of intraventricular and intraparenchymal cerebellar allografts in rat brain: Evidence for normal phosphorylation of neurofilaments. $J$. Neuroimmunol. 20: $63-72$.

116. Poltorak, M., AND W. J. Freed. 1990. Cell adhesion molecules in adrenal medulla grafts: Enhancement of chromaffin cell $\mathrm{L} 1 / \mathrm{Ng}$ - CAM expression and reorganization of extracellular matrix following transplantation. Exp. Neurol. 110: 52-72.

117. PoltoraK, M., K. ShIMOdA, AND W. J. FreEd. 1990. Cell adhesion molecules (CAMS) in adrenal medulla in situ and in vitro: Enhancement of chromaffin cell $\mathrm{L} 1 / \mathrm{Ng}$ - CAM expressions by NGF. Exp. Neurol. 110: 52-72.

118. Prochiantz, A., M.-C. Daguet, A. Herbet, and J. GloWINSKI. 1981. Specific stimulation of in vitro maturation of mesencephalic dopaminergic neurons by striatal membranes. $\mathrm{Na}$ ture (London) 293: 570-572.

119. Ricuarte, G. A., L. E. Delanney, I. IRWIN, AND J. W. LaNGSTON. 1987. Older dopaminergic neurons do not recover from the effects of MPTP. Neuropharmacology 26: 97-99.

120. Riopelle, R. J. 1988. Adrenal medulla autografts in Parkinson's disease: A proposed mechanism of action. Canad. $J$. Neurol. Sci. 15: 366-370.

121. RosensteIN, J. M. 1987. Adrenal medulla grafts produce blood-brain barrier dysfunction. Brain Res. 414: 192-196. 
122. Rosenstein, J. M. 1987. Neocortical transplants in the mammalian brain lack a blood-brain barrier to macromolecules. Science 235: 772-774.

123. Rosenstein, J. M., AND Brightman, M. W. 1986. Alterations of the blood-brain barrier after transplantation of autonomic ganglia into the mammalian nervous system. J. Comp. Neurol. 250: $339-351$.

124. SAGEN, J., AND J. E. KEMMLER. 1989. Increased levels of metenkephalin-like immunoreactivity in the spinal cord CSF of rats with adrenal medullary transplants. Brain Res. 502: 1-10.

125. SAgen, J., AND G. D. Parpas. 1988. Pharmacologic consequences of the vascular permeability of chromaffin cell transplants in CNS pain modulatory regions. Exp. Neurol. 102: 290-297.

126. SAgen, J., G. D. PAPPAS, AND J. D. OrTega. 1990. Host-graft relationships of isolated bovine chromaffin cells in rat periaqueductal grey. $J$. Neurocytol., in press.

127. Sagen, J., G. D. Pappas, and M. J. Perlow. 1986. Adrenal medullary tissue transplants in the rat spinal cord reduce pain sensitivity. Brain Res. 384: 189-194.

128. Sagfen, J., G. D. Pappas, and M. I. Pertow. 1987. Alterations in nociception following adrenal medullary transplants into the rat periaqueductal gray. Exp. Brain Res. 67: 373-379.

129. Sagen, J., G. D. Pappas, AND M. J. Perlow. 1987. Fine structure of adrenal medullary grafts in the pain modulatory regions of the rat periaqueductal gray. Exp. Brain Res. 67: 380-390.

130. Sagen, J., G. D. Pappas, AND H. B. Pollard. 1986. Analgesia induced by isolated bovine chromaffin cells implanted in rat spinal cord. Proc. Natl. Acad. Sci. USA 83: 7522-7526.

131. SAGEN, J., AND H. WANG. 1990. Prolonged analgesia by enkephalinase inhibition in rats with spinal cord adrenal medullary transplants. Eur. J. Pharmacol., 179: 427-433.

132. Sagen, J., H. Wang, AND G. D. PAppas. 1990. Adrenal medullary implants in the rat spinal cord reduce nociception in a chronic pain model. Pain, 42: 69-79.

133. Schachner, M., H. Antonicek, T. Fahring, A. Faissner, G. Fisher, V. Kunemund, R. Martini, E. Meier, E. Persohn, E. Pollenberg, R. Probstmeier, K. Sadoul, R. Sadoul, B. SEILHEIMER, AND G. Thor. 1988. Families of neural cell adhesion molecules. In The Cell in Contact: Structure and Function of Adhesion Molecules (G. M. Edelman and J.-P. Thiery, Eds.), Vol. 2. Wiley, New York.

134. SchwaB, R. S., AND A. C. ENGland, JR. 1969. Projection technique for evaluating surgery in Parkinson's disease. In Third Symposium on Parkinson's Disease (F. J. Gillingham and I. M. L. Donaldson, Eds.), pp. 152-157. Livingstone, Edinburgh.

135. Schwarz, S., ANd W. J. Freed. 1987. Brain tissue transplantation in neonatal rats prevents a lesion-induced syndrome of adipsia, aphagia, and akinesia. Exp. Brain Res. 65: 449-454.

136. SEIDL, K., AND K. UNSICKER. 1989. Survival and neuritic growth of sympathoadrenal (chromaffin) precursor cclls in vitro. Int. J. Dev. Neurosci. $7:$ 465-473.

137. Simonds, G. W., S. Schwarz, E. KRauthamer, and W. J. FREED. 1990. Effects of adrenal medulla grafts in neonatal rat hosts on subsequent bilateral substantia nigra lesions. Restorative Neurol. Neurosci. 1 : 315-322.

138. Slladek, J. R., D. E. Redmond, T. J. Collier, J. P. Blount, J. D. Elsworth, J. R. TAYlor, AND R. H. Roth. 1988. Fetal dopamine neural grafts: extended reversal of methylphenyltetrahydropyridine-induced parkinsonism in monkeys. Prog. Brain Res. 78: 497-506.

139. Snyder, S. R., D. SAHAR, A. L. N. Prasad, AND S. FahN. 1977.
Changes in adrenal dopamine concentration after metyrapone or ACTH administration: Implications for the in vivo regulation of dopamine $\beta$-hydroxylase by glucocorticoids. Life Sci. 20: 1077-1086.

140. Steece-Collier, K., T. J. Collier, C. D. Sladek, AND J. R. SLADEK. 1989. Chronic L-DOPA treatment decreases the viability of grafted and cultured embryonic rat mesencephalic dopamine neurons. Soc. Neurosci. Abstr. 15: 1354.

141. Stoddard, S. L., J. E. Ahlskog, P. J. Kelly, G. M. TyCE, J. A. van HeErden, A. R. Zinsmeister, and S. W. Carmichael. 1989. Decreased adrenal medullary catecholamines in adrenal transplanted Parkinsonian patients as compared to nephrectomy patients. Exp. Neurol. 104: 218-222.

142. Stromberg, I., AND T. EBendal. 1988. Aged adrenal medullary tissue survives intraocular grafting, forms nerve fibers and responds to NGF. In Chromaffin and Nigral Grafts (I. Stromberg, Ed.). Stockholm.

143. Stromberg, I., T. Ebendal, A. Seiger, ANd L. Olson. 1985. Nerve fiber production by intraocular adrenal medullary grafts: Stimulation by nerve growth factor or sympathetic denervation of the host iris. Cell Tissue Res. 241: 241-249.

144. Stromberg, I., A. Hultgardh-Nilsson, U. Hedin, and T. EBENDAL. 1988. Fate of intraocular chromaffin cell suspensions: Role of initial nerve growth factor support. Cell Tissue Res. 254: 487-497.

145. Strombfra, I., M. Hfrrefra-Marschitz, I. Hultgren, U. UNGERSTEDT, AND L. OLSON. 1984. Adrenal medullary implants in the dopamine-denervated rat striatum. I. Acute catecholamine levels in grafts and host caudate as determined by HPLC-electrochemistry and fluorescence histochemical image analysis. Brain Res. 297: 41-51.

146. Stromberg, I., M. Herrera-Marschitz, U. Ungerstedt, T. EBENDAL, AND L. OLsON. 1985. Chronic implants of chromaffin tissue into the dopamine-denervated rat striatum. Effects of NGF on graft survival, fiber growth and rotational behavior. Exp. Brain Res. 60: 335-349.

147. TANK, A. W., L. HAM, AND P. CURElla. 1986. Induction of tyrosine hydroxylase by cyclic AMP and glucocorticoids in a rat pheochromocytoma cell line: Effect of the inducing agents alone or in combination on the enzyme levels and rate of synthesis of tyrosine hydroxylase. Mol. Pharmacol. 30: 486-496.

148. Tanner, C. M., R. L. WaTts, R. A. E. Bakay, and K. C. PETRUK. 1989. Correspondence. N. Engl. J. Med. 321: 325.

149. Thoenen, H. 1975. Transsynaptic regulation of neuronal enzyme synthesis. In Handbook of Psychopharmacology (L. L. Iversen, S. D. Iversen, and S. H. Snyder, Eds.), Vol. 3, pp. 443475. Plenum, New York.

150. Tischler, A. S., R. A. Delellis, B. Biales, G. NunneMACHER, V. CARABBA, AND H. J. Wolfe. 1980. Nerve growth factor-induced neurite outgrowth from normal human chromaffin cells. Lab Invest. 43: 399-409.

151. Tischlek, A. S., R. L. Perlaman, G. Nunnemacher, G. M. MorSe, R. A. DeLellis, H. J. Wolfe, AND B. E. Sheakd. 1982. Long-term effects of dexamethasone and nerve growth factor on adrenal medullary cells cultured from young adult rats. Cell Tissue Res. 225: 525-542.

152. Tomozawa, Y., AND S. H. APPEL. 1986. Soluble striatal extracts enhance development of mesencephalic dopaminergic neurons in vitro. Brain Res. 399: 111-124.

153. Tyce, G. M., J. E. Ahlskog, S. W. Carmichael, S. L. CritTON, S. L. STODDARD, J. A. VAN HeERDEN, T. L. YAKSH, AND P. J. KeLly. 1989. Catecholamines in CSF, plasma, and tissue after autologous transplantation of adrenal medulla to the 
brain in patients with Parkinson's disease. J. Lab. Clin. Med. 114: 185-192.

154. Unsicker, K., B. Kirch, U. OTten, AND H. Thomnen. 1978. Nerve growth factor-induced fiber outgrowth from isolated rat adrenal chromaffin cells: Impairment by glucocorticoids. Proc. Natl. Acad. Sci. USA 75: 3495-350'.

155. UNSICKER, K., T. J. MILLAR, AND H. D. HoFMANN. 1982. Nerve growth factor requirement of postnatal rat adrenal medullary cells in vitro for survival, aggregate formation and maintenance of extended neurites. Dev. Neurosci. 5: 412-417.

156. UNSICKER, K., B. REIFFERT, AND W. ZIEGLER. 1980. Effects of cell culture conditions, nerve growth factor, dexamethasone, and cyclic AMP on adrenal chromaffin cells in vitro. In Histochemistry and Cell Biology of Autonomic Neurons, SIF Cells, and Paraneurons. (O. Eranko, Ed.), pp. 51-59. Raven Press, New York.

157. UNSICKer, K., J. Vey, H. D. HofmanN, T. H. MulleR, AND A. J. WILson. 1984. C6 glioma cell-conditioned medium induces neurite outgrowth and survival of rat chromaffin cells in vitro: Comparison with the effects of nerve growth factors. Proc. Natl. Acad. Sci. USA 81: 2242-2246.

158. UNSICKER, K., S. D. SkAPER, AND S. VARON. 1985. Developmental changes in the responses of rat chromaffin cells to neuronotrophic and neurite-promoting factors. Dev. Biol. 111: 425433.
159. UNSICKER, K., S. D. SKAPER, AND S. VARON. 1985. Neuronotrophic and neurite-promoting factors: Effects on early postnatal chromaffin cells from rat adrenal medulla. Dev. Brain Res. 17: 117-129.

160. VAqUero, J., R. MARTINEZ, AND S. Coca. 1990. Graft of adrenal tissue into the nervous system. Neurosurgery 26: 176.

161. Vaquero, J., R. Martinez, S. Oya, S. Coca, F. G. Salazar, AND M. I. COLADO. 1988. Transplantation of adrenal medulla into spinal cord for pain relief: Disappointing outcome. Lancet 2: 1315.

162. WatTs, R. L., R. A. E. BAKay, P. M. IUvONE, N. WATts, AND S. GRAHAM. 1988. Autologous adrenal-caudate transplantation in patients with Parkinson's disease (PD). Neurology 38(Suppl. 1): 143 .

163. Weiner, W. J., J. SANChez-RAMOS, AND C. Singer. 1989. Correspondence. $N$. Engl. J. Med. 321: 326.

164. Winn, S. R., L. Wahlberg, P. A. Tresco, AND P. Aebischer. 1989. An encapsulated dopamine-releasing polymer alleviates experimental Parkinsonism in rats. Exp. Neurol. 105: 244250.

165. Wurtman, R. J., L. A. Pohorecky, and B. S. Batiga. 1972. Adrenocortical control of the biosynthesis of epinephrine and proteins in the adrenal medulla. Pharmacol. Rev. 24: 411-426.

166. Wyate, R. J., R. STaub, AND W. J. Freed. 1988. An improved procedure for pressure-free insertion of tissue into the central nervous system. Prog. Brain Res. 78: 625-629. 